$1-1-2014$

\title{
Moocs and Legal Education: Valuable Innovation or Looming Disaster?
}

Philip G. Schrag

Follow this and additional works at: https://digitalcommons.law.villanova.edu/vlr

Part of the Legal Education Commons

\section{Recommended Citation}

Philip G. Schrag, Moocs and Legal Education: Valuable Innovation or Looming Disaster?, 59 Vill. L. Rev. 83 (2014).

Available at: https://digitalcommons.law.villanova.edu/vlr/vol59/iss1/3

This Article is brought to you for free and open access by Villanova University Charles Widger School of Law Digital Repository. It has been accepted for inclusion in Villanova Law Review by an authorized editor of Villanova University Charles Widger School of Law Digital Repository. 
2014]

\title{
MOOCS AND LEGAL EDUCATION: VALUABLE INNOVATION OR LOOMING DISASTER?
}

\author{
PhILIP G. SCHRAG*
}

\section{INTRODUCTION}

$\mathrm{T}$ HE MOOCs are coming. Scratch that; they are already here. Massive open online courses (MOOCs)-distance learning with interactive bells and whistles, available via the internet throughout the world-have burst upon the world of education and are proliferating rapidly. Throughout 2012, these courses were offered primarily to undergraduate students and to people who were not enrolled in any academic institution. In that year, completion of a MOOC usually did not provide credit toward an academic degree, and nearly all MOOCs were free of charge to students. But in 2013, four new developments occurred. MOOCs on legal subjects became available for the first time. Universities and MOOC-producing corporations began to create business models through which students could be charged tuition for taking MOOCs for credit toward degrees. Undergraduate institutions and some law schools began offering credit for MOOC-based courses. And a major law school announced plans for awarding online LL.M. degrees. These concurrent evolutionary changes suggest that in the future, MOOCs might become an important aspect of the law school curriculum, or that MOOCs could even displace traditional legal education.

In this article, I describe the rapid evolution of MOOCs and speculate on how MOOCs may change legal education during the next decade. MOOCs bring organized information to very large numbers of people, and much of the literature on MOOCs perceives this development as an unalloyed benefit. But while MOOCs may therefore ultimately enable more people to earn law degrees, they will likely dilute the education offered to those future lawyers. They may also hasten the demise of many traditional law schools.

Part II describes MOOCs, their nature, and the investments that have fueled them. It also reviews the literature extolling the value of MOOCs. Part III explores the search by MOOC developers for a viable business model and the current debate within universities over whether academic credit should be granted for courses taught through MOOCs. Part IV considers the possible relevance for legal education of the coming MOOC

* Delaney Family Professor of Public Interest Law, Georgetown University. The author appreciates the assistance of Mabel Shaw, assistant foreign and international law librarian at the Georgetown University Law Library and the comments of Marc Galanter, Frank Pasquale, and Zachary Schrag on an earlier draft of this article. 
"avalanche"1 or "tsunami."2 It suggests three scenarios in which law schools may respond to two simultaneous developments: the economic crisis in legal education and the rapid technological advances that have dramatically lowered the costs of distance learning. In one of these scenarios, a few elite law schools will survive, but most law schools will disappear, leaving students to learn to become lawyers by interacting with computers in their homes or with the screens on their smart phones while they jog to their gyms or jobs. But perhaps we can do better.

\section{MOOCs AND TheIR ENTHUSIASTS}

Distance learning is nothing new. A book offers a type of distance learning; the author is rarely face-to-face with members of her audience but can educate vast numbers of readers throughout the world through propagation of her printed words. Radio and television added another dimension to distance learning; an educator's voice and image, as well as other sounds and images, could be spread to learners at least through the nation, and sometimes internationally. But educational broadcasting never really took off. ${ }^{3}$

The advent of the internet significantly lowered the cost of transmitting the equivalent of video programming to large numbers of people. Every person who had access to a computer could select among an enormous amount of video content and could view it on an individually chosen schedule. Restrictions imposed by televised bandwidth, and by limited time slots for broadcasting and rebroadcasting particular content, became irrelevant, as did the inconvenience of tuning in to a broadcast from a distant time zone. The internet also made it possible for those in the "audience" to talk back or to contribute content (by posting comments on a discussion thread).

Massive open online courses ${ }^{4}$ may be just a further step in the continuum of bringing technology to education. Or they may represent such a

1. Helena Gillespie, The MOOC Avalanche, Huffington Post U.K. (May 7, 2013), http://www.huffingtonpost.co.uk/helena-gillespie/mooc-avalanche_b_322 8870.html.

2. Ken Auletta, Get Rich U., The New Yorker (Apr. 30, 2012), http://www .newyorker.com/reporting/2012/04/30/120430fa_fact_auletta (quoting John Hennessy, President of Stanford University).

3. See Andrew Delbanco, MOOCs of Hazard, New Republic (Mar. 31, 2013), http:/ /www.newrepublic.com/article/112731/moocs-will-online-education-ruinuniversity-experience ("From 1957 to 1982, the local CBS channel in New York City broadcast a morning program of college lectures called 'Sunrise Semester.' But the sun never rose on television as an educational 'delivery system.'”).

4. See Ann Kirschner, A Pioneer in Online Education Tries a MOOC, CHron. OF Higher Educ. (Oct. 5, 2012), http://chronicle.com/article/A-Pioneer-in-OnlineEducation/134662/ (noting that term has been derided as "one of the ugliest acronyms of recent years"). The term was coined in 2008 by Dave Cormier, the manager of web communications and innovations at the University of Prince Edward Island. See Audrey Watters, Top Ed-Tech Trends of 2012: MOOCs, Hack Educ. (Dec. 3, 2013), http://hackeducation.com/2012/12/03/top-ed-tech-trends-of-2012- 
dramatic departure from previous forms of distance learning that they deserve the approving phrase that their advocates use to describe them: "disruptive technology." What the MOOC developers hope to disrupt is higher education as it has been practiced for at least a century. ${ }^{6}$

\section{A. What Are MOOCs?}

MOOCs are internet-based courses that are built around pre-recorded video presentations, often by professors who are famous in their fields, which may incorporate still images, audio recordings, or other videos. In some MOOCs, the length of each presentation is similar to the length of a university lecture, but in others, they may be offered as shorter units, ten to twenty minutes each. Students can watch the lectures at any hour of the day. But MOOCs are more than one-way presentations. They also include assigned readings that can be perused online or printed from a website, computer-administered quizzes and examinations, an associated website on which students can post essays in response to assignments or write messages to each other in virtual study groups, links to websites with related material, and, at least for science courses, simulated laboratories. Some MOOCs include "tools for students to plan 'meet-ups' with [other students] in about 1,400 cities worldwide," though it has been known to happen that at the appointed time, nobody shows up. ${ }^{7}$

The proliferation of MOOCs in 2012 resulted from the work of three computer science professors at Stanford University. In 2008, Andrew Ng, then 32, was using artificial intelligence software to enable helicopter drones to learn to fly themselves. He was also teaching courses but disliked how much of his time was taken up by grading. He thought about how to automate higher education and concluded that, at least in the hard sciences, computers could not only grade problem sets but could provide

moocs/ (referring to Dave Cormier, University of Prince Edward Island, http:// integratedcommunications.upei.ca/staff/dave-cormier). "The term 'MOOCs' is meant to parallel the video-game acronym 'MMOGs,' or massively multiplayer online games ...." Jeffrey R. Young, What Professors Can Learn from 'Hard Core' MOOC Students, Chron. of Higher Educ. (May 20, 2013), http://chronicle.com/article/ What-Professors-Can-Learn-From/139367/.

5. See, e.g., Catharine R. Stimpson, On Becoming a Phoenix: Encounters with the Digital Revolution, Chron. of Higher Educ. (Oct. 5, 2012), http://chronicle.com/ article/On-Becoming-a-Phoenix-/134658/.

6. See D.D. Guttenplan, Europeans Take a More Cautious Approach Toward Online Courses, N.Y. Times (Feb. 17, 2013), http://www.nytimes.com/2013/02/18/world/ europe/18iht-educside18.html?_r=0. To date, MOOC development is primarily an American phenomenon, as "the reaction in Europe is distinctly cautious" although European educators may be "desperately playing catch-up." See id.

7. See Laura Pappano, The Year of the MOOC, N.Y. Times (Nov. 2, 2012), http:/ /www.nytimes.com/2012/11/04/education/edlife/massive-open-online-coursesare-multiplying-at-a-rapid-pace.html. 
hints or other guidance to students who, responding to assignments on computers, were making mistakes that the computer could recognize. ${ }^{8}$

At about the same time, his Stanford colleague, Sebastian Thrun, was also turning his attention from education. Thrun, one of the world's leading robotics experts, had increasingly done work with Google while teaching at Stanford. He founded Google's X Lab and led the teams that developed Google's self-driving car and Google glass. In 2011, he taught an online course on artificial intelligence which was begun by $160,000 \mathrm{stu}-$ dents and completed by 23,000 students. The following year, he resigned from his tenured position at Stanford (where he still teaches on a parttime basis), to devote most of his time to educational reform through technology. ${ }^{9}$

In 2012, $\mathrm{Ng}$ and his Stanford computer science department colleague, Daphne Koller, founded Coursera, a for-profit company to create and offer MOOCs, and Thrun founded Udacity for the same purpose. ${ }^{10}$ Neither company's founders had a clear conception of how they would make money, but start-up funding came easily to professors with genius reputations. Coursera received more than $\$ 18$ million in venture capital from New Enterprise Associates and Kleiner Perkins Caufield \& Byers during its months, in addition to an investment of nearly $\$ 4$ million by the California Institute of Technology and the University of Pennsylvania. ${ }^{11}$ Udacity initially obtained \$5 million from Charles River Ventures, ${ }^{12}$ and within a year, it had raised more than $\$ 21$ million. ${ }^{13}$

MOOC corporations and universities gave grants of tens of thousands of dollars to professors willing to create MOOCs and offered the online courses for free. ${ }^{14}$ In short order, very large numbers of people signed up

8. See Jeffrey R. Young, From Self-Flying Helicopters to Classrooms of the Future, Chron. of Higher Educ. (Oct. 5, 2012), http://chronicle.com/article/From-SelfFlying-Helicopters/134666/.

9. See George Anders, How Would You Like a Graduate Degree for $\$ 100$ ?, Fonbes (June 25, 2012), http://www.forbes.com/sites/georgeanders/2012/06/05/ udacity-sebastian-thrun-disrupting-higher-education/; see also Katherine Mangan, MOOC Mania: It's Raising Big Questions About the Future of Higher Education, CHrON. of Higher Educ. (Oct. 5, 2012), http://chronicle.com/article/Massive-Excitement-About/134678 (attracting 160,000 students).

10. See Leadership, CourSERA, https://www.coursera.org/about/founders (last visited Sept. 30, 2013); see also About Us, UdACITY, https://www.udacity.com/us (last visited Sept. 30, 2013); Mangan, supra note 9; Young, supra note 8.

11. See Young, supra note 8.

12. See Anders, supra note 9; see also Ari Levy, Udacity Raises $\$ 15$ Million as Money Pours into Online Education, Bloomberg Tech Deals (Oct. 25, 2012), http:// go.bloomberg.com/tech-deals/2012-10-25-udacity-raises-15-million-as-moneypours-into-online-education/.

13. See Levy, supra note 12; see also Rip Empson, Coursera Takes a Big Step Toward Monetization, Now Lets Students Earn "Verified Certificates" for a Fee, TECHCRUNCH EDuc. (Jan. 8, 2013), http://techcrunch.com/2013/01/08/coursera-takes-a-bigstep-toward-monetization-now-lets-students-earn-verified-certificates-for-a-fee /.

14. Goldie Blumenstyk, Company Offers Cash Prizes to Lure Professors to Teach MoOCs, Chron. of Higher Educ. (Apr. 25, 2013), http://chronicle.com/blogs/ 
for some of them. By the end of 2012, the "year of the MOOC," 15 Coursera had more than 2 million registrants, and several of its courses had registrations of more than 100,000 students, ${ }^{16}$ although completion rates hovered around $12 \%$ and in some difficult courses fell to $2 \% .{ }^{17}$ By May 2013, Coursera was offering 370 different courses, ${ }^{18}$ and it had signed partnership agreements with thirty-three universities, including Princeton, Brown, and Columbia. ${ }^{19}$

Six-digit course registration numbers for courses managed by forprofit companies soon caught the eye of professors and administrators at the nation's most prestigious universities. Within months of the founding of Coursera and Udacity, MIT and Harvard teamed up to form a nonprofit alternative to these enterprises. With $\$ 30$ million of their own funds, they started edX, invited a few other well-known colleges and universities to join them (contributing additional funds of their own), and encouraged their professors to create MOOCs. ${ }^{20}$ By May 2013, edX was offering thirty-three "free courses from leading universities" ${ }^{21}$ taught by

wiredcampus/company-offers-cash-prizes-to-lure-professors-to-teach-moocs/ 43583. Most compensation information is not public at this time. See id. However, Iversity, a German MOOC company, offered $\$ 25,000$ euros each to ten academic MOOC developers. See id. Georgetown University, an edX member, offered faculty members grants of up to $\$ 100,000$ to develop MOOC versions of their courses. See Initiative on Technology-Enhanced Learning, Funding Categories, GEORGETOWN U., https://itel.georgetown.edu/fall2013/mooc-track/ (last visited Feb. 17, 2014). Three professors at San Jose State University are each being paid $\$ 15,000$ to develop a pilot MOOC in introductory mathematics for Udacity. See Jeffrey R. Young, California State U. Will Experiment with Offering Credit for MOOCs, Chron. of Higher Educ. (Jan. 15, 2013), http://chronicle.com/article/California-State-U-Will/136677 [hereinafter California State U.]. The total cost of producing a MOOC is, on average, about $\$ 50,000$. See Tamar Lewin, Students Rush to Web Classes, but Profits May Be Much Later, N.Y. Times (Jan. 6, 2013), http://www.nytimes .com/2013/01/07/education/massive-open-online-courses-prove-popular-if-notlucrative-yet.html?_r=0. The largest expenses are for videography to pay teaching assistants to monitor the MOOC's discussion forum. See id.

15. See Pappano, supra note 7; see also Watters, supra note 4.

16. See Steve Kolowich, Wielding 'Power Users', Inside Higher Ed (Nov. 29, 2012), http://www.insidehighered.com/news/2012/11/29/coursera-looks-har ness-free-labor-its-devotees.

17. See id.

18. See Courses, Coursera, https://www.coursera.org/courses (last visited May 8, 2013) [hereinafter Coursera Courses]. At the same time, Udacity was offering twenty-five courses. See Courses, UdAciTy, https://www.udacity.com/courses (last visited May 8, 2013) [hereinafter Udacity Courses].

19. See Pappano, supra note 7.

20. See, e.g., Georgetown Joins Harvard and MIT's edX to Enhance Learning on Campus, Globally, GeORGETOwn U. (Dec. 10, 2012), http://www.georgetown.edu/news/ edx-georgetown.html. Georgetown University became the sixth member of edX in December 2012. See id. This author has no involvement in the Georgetown effort and is not developing or offering a MOOC.

21. See Take Great Courses, EDX, https://www.edx.org/courses (last visited May $8,2013)$. 
faculty members from Harvard, MIT, the University of Texas at Austin, and the University of California at Berkeley. ${ }^{22}$

Most MOOCs offered during the first year of these companies' operations dealt with subjects related to science and technology. Of the 370 courses offered by Coursera in May 2013, 304 were listed in fields of science and mathematics. ${ }^{23}$ Udacity listed twenty-five courses; seventeen of them were in computer science, five in mathematics, and one each in physics, psychology, and business. ${ }^{24}$ EdX listed thirty-five courses, twentynine of which dealt with science, mathematics, and engineering. ${ }^{25}$ The initial focus of MOOCs on the natural sciences was probably a result of two factors. First, the creators of the MOOCs were themselves experts in computer science and undoubtedly knew colleagues, both at Stanford and elsewhere, who could be interested in offering MOOCs. More important, courses in science, mathematics, and particularly computers are wellsuited for MOOCs. In a computer science course, the MOOC can assign exercises such as the creation of bits of code which the student performs on his own computer while taking the MOOC, and MOOC software can instantly evaluate whether or not the task has been performed correctly. It can also respond to common errors by providing instant feedback to point the student in the right direction. In addition, science and mathematics questions tend to have correct answers, or at least less often involve matters of opinion than questions in the humanities and social sciences, so it is relatively easier for the programmer to design quizzes and tests and for the computer to grade them.

22. See id. Within the overall "edX" name, the affiliated universities are offering online courses from "HarvardX," "MITx," and the like. See id. Why do they use these names? Marc Bousquet, a professor of English at Emory University, suggests that these universities "are trying to have their brand cake and dilute it too by branding their Edx courses as the product of 'Harvardx' and MITx.'" Marc Bousquet, Good MOOC's, Bad MOOC's, Chron. of Higher Educ. Blog (July 25, 2012), http://chronicle.com/blogs/brainstorm/good-moocs-bad-moocs/50361.

23. See Take Great Courses, supra note 21. Coursera itself grouped its courses by fields. See Coursera Courses, supra note 18. The 304 science courses included 42 courses in biology and life sciences, 9 in chemistry, 86 in computer science, 12 in energy and earth sciences, 21 in engineering, 43 in health and society, 35 in information, technology, and design, 3 in physical and earth sciences, 17 in physics, and 26 in statistics and data analysis. See id. Other fields with substantial numbers of Coursera courses included "humanities" (64 courses) and "education" (44 courses). See id. Coursera counts some courses in two different fields; for example, "Nutrition, Health and Life Style" was listed both in "Biology and Life Sciences" and in "Food and Nutrition." See id.

24. See Udacity Courses, supra note 18.

25. See Take Great Courses, supra note 21. The courses that were not on natural sciences subjects were "Ideas of the 20th Century," "The Ancient Greek Hero," "Justice," "The Challenges of Global Poverty," "Copyright," and "Age of Globalization." See id. 


\section{B. Enthusiasm for MOOCs}

Early reporting on MOOCs has featured statistics showing the impressively large numbers of students who enroll in some of the most popular courses. They include such offerings as computer science by David Malan (Harvard), with more than 100,000 participants; ${ }^{26}$ Ancient Greek Heroes by Gregory Nagy (Harvard) with 27,000 students, ${ }^{27}$ Introduction to Finance by Gautam Kaul (Michigan), with 130,000 students, ${ }^{28}$ and Sebastian Thrun and Peter Norvig's Artificial Intelligence course with 160,000 enrollees. $^{29}$ Even much smaller MOOCs, such as the Operations Management course taught by Northwestern's Gad Allon, with 4,400 students, have audiences quite a bit larger than teachers can reach in traditional university classrooms. ${ }^{30}$

Teachers who provide these offerings often express their enthusiasm. Princeton's Mitchell Duneier offered a Coursera course on Introductory Sociology to 40,000 students. He reported that when he lectures on C. Wright Mills's The Sociological Imagination in a lecture hall:

I usually receive a few penetrating questions. In this case, however, within a few hours of posting the online version, the course forums came alive with hundreds of comments and questions. Several days later there were thousands. Although it was impossible for me to read even a fraction of the pages of students' comments ... . I was quickly able to see the issues that were most meaningful .... I arranged live exchanges via a video chat room, in which six to eight students from around the world-some selected from the online class, others volunteers here at Princeton-participated with me in a seminar-style discussion ... while thousands of their online classmates listened to the live stream or to recordings later. ${ }^{31}$

Duneier was particularly pleased with having an international student body in which students could communicate with each other:

There were spontaneous and continuing in-person study groups in coffee shops in Katmandu and in pubs in London. . . . [Some

26. See Jeff Dunn, The 11 Most Popular Open Online Courses, Edudemic (Dec. 23, 2012), http:/ /www.edudemic.com/the-11-most-popular-open-online-courses/.

27. See Richard Perez-Pena, Harvard Asks Graduates to Donate Time to Free Online Humanities Class, N.Y. Times (Mar. 25, 2013), http://www.nytimes.com/2013/03/ 26/education/harvard-asks-alumni-to-donate-time-to-free-online-course.html?_r=0.

28. See Ben Gose, 4 Massive Open Online Courses and How They Work, Chron. of Higher Educ. (Oct. 1, 2012), https://chronicle.com/article/Massive-ExcitementAbout/134664/.

29. See Dunn, supra note 26.

30. See Gose, supra note 28.

31. See Mitchell Duneier, Teaching to the World from Central New Jersey, Chron. of Higher Educ. (Sept. 3, 2012), http://chronicle.com/article/Teaching-to-theWorld-From/134068/. 
students] got to know those [other students whose postings on the course website revealed] a common particular interest, such as racial differences in $\mathrm{IQ}$, the prisoner abuses that took place at Abu Ghraib, or ethnocentrism ... . [One student posted a comment stating that], "It started as intellectual activity but it's ending in an indescribable emotional relationship with all my classmates." 32

Similarly, Michael S. Roth, president of Wesleyan University, intrigued "by the prospect of sharing my class with a large, international group of people who wanted to study," taught a Coursera MOOC on The Modern and the Postmodern. ${ }^{33}$ He was "surprised that almost 30,000 people enrolled in the course," but worried that because he improvises his lectures, "some silly joke I make about Freud could go viral and become my epitaph."34 Nevertheless, he was impressed when, after the first lecture, he found online study groups forming in Spain, Portugal, Bulgaria, Russia, the United States, and India, and by the diversity of the ages and prior education of the students. What pleased him the most were the discussion threads, in which students reacted to the course; one talked about the class "igniting" his fire for learning, one about never having had the opportunity to attend a university. One enrolled with his mother so that they could discuss the material together, and one reported being "captured" by Baudelaire. "It's the differences among [the students], and how they bridge those differences through social networks, that energize their MOOC experience and mine." 35

Students who have written about taking MOOCs tend to report satisfaction as well. For example, Joe Alfonso, a financial planner, took Professor Kaul's Introduction to Finance MOOC as a refresher course. He reported that: "In a weird way, you have this connection with [Professor Kaul]. You almost feel like he's speaking directly to you."36 The lecture segments were only twenty minutes long, so Mr. Alfonso could fit them in between meetings with clients. ${ }^{37}$ Jacqueline Spiegel, a "mother of three from New Rochelle, N.Y., with a master's in computer science from Columbia" offered a similar observation: "You feel like you are sitting next to someone and they are tutoring you." 38 She tried taking in the lectures on her smart phone during a daughter's ice skating lessons but was able to

32. See id. Duneier later became disillusioned and stopped teaching his course. For a discussion of Duneier's opinion, see infra note 127 and accompanying text.

33. Michael S. Roth, My Modern Experience Teaching a MOOC, CHron. OF Higher Educ. (Apr. 29, 2013), http://chronicle.com/article/My-Modern-MOOCExperience/138781/.

34. Id.

35. See id.

36. Gose, supra note 28.

37. See id.

38. Pappano, supra note 7. 
concentrate better when watching them on her desktop. She also made friends with women in South Asia who were taking the same course and started an online study group for women taking science and technology MOOCs. ${ }^{39}$

A.J. Jacobs, an editor at large for Esquire magazine, signed up for eleven MOOCs, finished the two with "lighter workloads and less jargon," and wrote up his experience for the New York Times. ${ }^{40}$ He gave them an overall grade of "B." He gave them an "A" for convenience (he watched lectures while striding on his treadmill and while eating a spinach salad, and he watched some at double speed), but a " $\mathrm{D}$ " for teacher-student interaction (he lost a lottery for an exclusive ten-person Google hangout with a genetics professor and was not among the "handful of lucky students" who received responses from professors on the discussion boards ). ${ }^{41}$ Although he reported that, " $[\mathrm{M}]$ y retention rate was low, and I can't think of any huge practical applications for my newfound knowledge," he was glad that he spent the time because "MOOCs provided me with the thrill of relatively painless self-improvement and an easy introduction to heady topics. . . [ [As well as] relief from the guilt of watching 'Swamp People.'"42

But most of the published praise for MOOCs has come from "motivated students, often adults, who seek to build on what they have already learned in traditional educational settings." 43 It is too early to assess whether they will be equally popular or valuable for more easily distracted college students (or law students).

Some of the reports on high enrollments in MOOCs include the caveat that the percentage of dropouts from such courses is very high, as Jacobs's experience demonstrates. For example, 154,763 people signed up for an electronic circuit course offered on MITx, the precursor of edX. But only 69,221 of them looked at the first problem set, only 26,329 received at least one point on that set, only 9,318 passed the midterm exam, and only 5,800 passed the final exam. It was possible to pass the course without passing that exam (by doing well on the problem sets), but even so, only 7,157 students completed the course successfully, a $5 \%$ pass rate based on original enrollment. ${ }^{44}$ Coursera offered a 2012 MOOC in Social Network Analysis. About 61,000 students enrolled, but only 1,303 (2\%) earned a certificate for completing it, and only $145(.24 \%)$ submitted a

39. See id.

40. See A. J. Jacobs, Two Cheers for Web U!, N.Y. Times (Apr. 20, 2013), http:// www.nytimes.com/2013/04/21/opinion/sunday/grading-the-mooc-university .html.

41. See id.

42. $I d$.

43. See Delbanco, supra note 3.

44. See Sue Gee, MITx: The Fallout Rate, I Programmer (June 16, 2012), http:/ /www.i-programmer.info/news/150-training-a-education/4372-mitx-the-falloutrate.html. 
final project of whom $107(.17 \%)$ earned the equivalent of a certificate with distinction. ${ }^{45}$ The overall MOOC completion rate is reportedly around $10 \% .46$

The dropout rate does not trouble most of the MOOC enthusiasts, however. As Michael Roth explained: "[S]aying someone 'failed to complete' a free open online class is like saying someone 'failed to complete' The New Yorker . . . . Most don't sign up for the class or the magazine for purposes of 'completion.'" 47 In other words, it isn't appropriate to compare the dropout rate for MOOCs to those of college courses for which students receive credit and pay tuition, or to anticipate that the dropout rate would remain so high if students received degree credit or were paying for the experience.

\section{MOOCs for College Credit: The Search for a Business Model}

Venture capital firms-and universities-do not usually provide services out of charitable motives. They seek revenue. To date, nearly all of the MOOCs have been provided free of charge to those taking the courses. Doing so has made good business sense for Coursera and Udacity, establishing themselves as the front-runners in what could turn out to be an important new industry. It has also made good business sense for the initial university members of edX, providing vast amounts of free publicity to them (particularly to Harvard and MIT), and even more widely spreading the brand names of schools whose brands were already known throughout most of the world.

But the three entities, as well as smaller MOOC-making companies, are frantically trying to design a business model that will produce substantial revenues-profits for the for-profit firms, and reimbursement and new revenues for the non-profit universities that funded edX. Some of the MOOC backers are patient. "We invest with a very long mind-set, and the gestation period of the very best companies is at least 10 years," a Coursera financier said. ${ }^{48}$ But others, particularly university officials, are less patient. "We don't want to make the mistake the newspaper industry did, of giving our product away free online for too long," one university provost told the New York Times. ${ }^{49}$ EdX, the non-profit, may be the least patient MOOC provider. Harvard's online courses were free in 2011 and 2012, but Harvard planned to begin "revenue experiments" in the fall of 2013, because " $[\mathrm{t}]$ he university regards its thirty-million-dollar pledge [to edX]

45. See Alan Levine, Owning Your Massive Numbers, Cogdogblog (Nov. 27, 2012), http://cogdogblog.com/2012/11/27/owning-massive/.

46. See Delbanco, supra note 3.

47. See Roth, supra note 33. It is not apparent that anyone has yet surveyed MOOC dropouts to learn why they did not complete the courses.

48. See Lewin, supra note 14 (quoting Scott Sandell, partner at New Enterprise Associates).

49. See id. (quoting Peter Lange, Provost of Duke University). 
as a 'venture capital' type of investment, and hopes to get its money back." 50

Their thinking to date has revolved primarily around three ideas: (1) selling names and contact information for successful MOOC graduates to potential employers, (2) selling certificates of completion to those who take MOOCs, and (3) selling MOOCs for university course credit, either by licensing lectures or whole courses to universities (with the universities paying the companies for the rights), or by persuading universities to accept MOOCs for course credit, with the students paying the companies for credits that they could use at any of several universities. ${ }^{51}$ Under either of these university course-for-credit models, both the MOOC companies and the universities would share in the revenues from tuition. Under the first of those course credit plans, a university would pay either a flat fee or a per-student fee for its students to take a MOOC for credit, and the university would charge the student, just as universities do now for students in residence. Under the other plan, the individual student would pay "tuition" to the MOOC provider and would receive transfer credits that could be applied toward a degree at any university that is willing to accept them, just as high school students who take advanced placement courses or college students who transfer to another school receive credit for courses taken elsewhere.

\section{A. Selling Customer Information}

One early foot in the door into the world of profit is the relationship that Udacity is building with corporate employers, particularly those in the high-tech world, where Udacity's courses are concentrated. The company is already selling contact information for its "high performing students" to Facebook and Twitter, among others. ${ }^{52}$ Udacity charges less than employers would have to pay professional talent-hunting companies for similar referrals. ${ }^{53}$

Coursera has gotten into this business as well. When a company is looking for an entry-level candidate with particular skills, it contacts Coursera, which emails one of its students to obtain consent. The company introduces the student to the employer, and when an employment offer is

50. See Nathan Heller, Laptop U: Has the Future of College Moved Online?, THE New Yorker (May 20, 2013), http:/ / www.newyorker.com/reporting/2013/05/20/ 130520fa_fact_heller.

51. See Jeffrey R. Young, Inside the Coursera Contract: How an Upstart Company Might Profit from Free Courses, Chron. Of Higher Educ. (July 19, 2012), http:// chronicle.com/article/How-an-Upstart-Company-Might/133065/. Selling banner ads along with educational material has also been mentioned as a possible revenue source for MOOC providers but does not seem likely to flourish, at least so long as university professors are providing the content or universities are offering credit for taking the courses. See id.

52. See Lewin, supra note 14.

53. See Delbanco, supra note 3. 
accepted, the employer pays Coursera a finder's fee, a portion of which goes to the university whose faculty member designed the course. ${ }^{54}$

\section{B. Selling Certificates of Completion}

Coursera gives away or sells certificates of completion to students who complete its courses. Presumably students who purchase the certificates believe that the credential will help them to gain employment, and company officials may hope that the certificates will eventually become alternatives to college or university degrees, at least in specialized, technical fields, which would give them great value. At least some of these certificates are issued jointly by Coursera and by the university of the professor who taught the course. ${ }^{55}$

Actually, Coursera offers at least three different kinds of certificates. The basic certificate, a "Statement of Accomplishment," is, at present, free of charge to those who sign the "honor code" electronically and satisfy the course requirements (which may include homework, tests, and a final examination). The Coursera "Honor Code" states that "My answers to homework, quizzes and exams will be my own work," that the student "will not make solutions to homework, quizzes or exams available to anyone else" and that the student will "not engage in any other activities that will dishonestly improve" the student's results. ${ }^{56}$ At least at present, Coursera does not police compliance with the code for those who receive the basic certificate, so it is possible for a student to cheat by having someone else help with the tests or even sign in with the student's account and complete the tests online.

At the second level, a "Statement of Accomplishment with Distinction" is provided, also at no charge, to students who do extra work. For example, in one of Coursera's first forays into legal education, its course on International Criminal Law taught by Professor Michael P. Scharf of Case Western Reserve University, students who viewed all eight video sessions and correctly answered at least six of the ten true-false questions on the final examination received the basic Statement of Accomplishment, but those who posted at least five online submissions of at least 200 words received statements "With Distinction." 57

At the third level, revenue from the student plays a role. Coursera has created a "Signature Track" through which a student can earn a "Verified

54. See id. One author has suggested that selling lists of successful students to corporate recruiters "could raise privacy concerns." See Mangan, supra note 9. But presumably obtaining student consent eliminates that problem. See id. text.

55. For a discussion of these certificates, see infra note 59 and accompanying

56. See Honor Code, Coursera, https://www.coursera.org/about/honorcode (last visited Nov. 10, 2013).

57. See Michael Scharf, Introduction to International Criminal Law, Syllabus, COURSERA, https://class.coursera.org/intlcriminallaw-001/wiki/view?page=sylla bus (last visited May 14, 2013). 
Certificate" of Accomplishment. ${ }^{58}$ Students in Professor Scharf's course could earn a Verified Certificate of Accomplishment by paying $\$ 49$, an "introductory price" discount from the "regular" \$69 price. ${ }^{59}$ According to Coursera, this certificate would constitute "official recognition" from Case Western Reserve University which could help someone who had completed the course to "Build your qualifications and prove yourself in something new." The certificate would enable its holder to highlight your course on "your resume or CV and along with applications," and "anyone you choose" can see your detailed score, the course syllabus, and workload. ${ }^{60}$

Coursera has developed a system to make it likely that the person who receives a "verified" certificate is actually the person who took the course. During one of the first few course sessions, the student must communicate his or her "personal typing pattern" to Coursera:

Much like your handwriting style, your typing pattern is unique to you. As part of your Signature Profile, you'll capture your personal typing pattern, which includes the time between your keystrokes and the amount of time you press a key down (in milliseconds).

To create a sample of your typing pattern, you'll type a short sentence (provided by our system) into a special field twice.

Our system will learn to recognize your personal typing pattern, which you can then begin to use to link your coursework to your identity. ${ }^{61}$

In addition, the student must transmit electronically to Coursera a headshot taken by a webcam, and a copy of a passport or governmentissued photo identification. Each time the student submits homework or completes a test, the student must provide a typing sample, a webcam

58. See Rip Empson, Coursera Takes a Big Step Toward Monetization, Now Lets Students Earn "Verified Certificates" for a Fee, TeсhCrunch (Jan. 8, 2013), http:// techcrunch.com/2013/01/08/coursera-takes-a-big-step-toward-monetization-nowlets-students-earn-verified-certificates-for-a-fee/.

59. See Signature Track Guidebook, Coursera, https://www.coursera.org/signature/guidebook (last visited May 15, 2013) [hereinafter Coursera Guidebook]. The price of a verified certificate depends on the course, and currently the fee may be as high as $\$ 100$. See id.; see also Empson, supra note 58. Coursera has its own financial aid program. See Coursera Guidebook, supra. Students may apply for financial aid electronically. See id. The application process requires them to show that "paying the cost of joining a course's Signature Track would cause economic hardship. ... [And] that the Verified Certificate is of significant value to [the student's] education or career." Id. The applicant must also "[d] emonstrate values of academic integrity and contribute positively to the course's community." Id.

60. See The Anatomy of a Verified Certificate $\mathcal{E} \mathcal{O}$ Shareable Course Records, CourserA BLOG (Nov. 10, 2013 3:00 PM), http://blog.coursera.org/post/49446662335/theanatomy-of-a-verified-certificate-shareable.

61. Coursera Guidebook, supra note 59. 
photo, or both to confirm that the person submitting the work is the person in whose name the verified certificate will be issued. ${ }^{62}$

According to one user, however, "this system is not without its flaws. It can easily be circumvented by merely giving your login credentials to another test-taker and having them 'Save Answers.' Then the registered student can login again and just 'Submit Answers' anytime before the deadline." ${ }^{3}$ Presumably Coursera and others will develop even more secure verification systems as students exploit weaknesses in the companies' current methods.

\section{Selling MOOCs for Course Credit}

Until substantial numbers of employers begin to regard MOOC certificates as valid substitutes for university education, sales of $\$ 69$ certificates are unlikely to provide the revenues to fuel a new industry. The prospect of offering degree credit for MOOCs is therefore far more likely to generate significant revenues, but for several reasons, it is a controversial proposition. The concerns that objectors have raised involve the integrity of the grading process, uncertainties about the quality of the courses, and the concern that widespread acceptance of MOOCs will destroy many long-established educational institutions, starting with community colleges and small, lower-prestige four-year colleges.

Even though MOOCs are a very new phenomenon, and MOOCs for credit are an even newer idea, some institutions of higher education are already offering credit for MOOC completion. In September 2012, the Global Campus of Colorado State University ${ }^{64}$ announced that it would give three course credits to transfer students who successfully completed Udacity's MOOC in "Introduction to Computer Science: Building a Search Engine," an offering with 200,000 enrollees. To receive the credit, students would also have to take a test that is proctored online. ${ }^{65}$ The cost for the college credit would be only $\$ 89$, compared with the usual $\$ 1050$

62. See id. EdX has announced that it will also sell verified completion certificates. See ID Verified Certificates of Achievement, EDX, https://www.edx.org/verifiedcertificate (last visited Oct. 4, 2013).

63. 沈, The Coursera Signature Track Experience, School Is Broken (Nov. 10, 2013 3:00 PM), http://brokenschool.wordpress.com/2013/04/21/the-courserasignature-track-experience/.

64. The Global Campus is the university's completely online school; it is accredited and offers both undergraduate and master's degrees. See Katherine Mangan, A First for Udacity: A U.S. University Will Accept Transfer Credit for One of Its Courses, Chron. of Higher Educ. (Sept. 6, 2012), http://chronicle.com/article/AFirst-for-Udacity-Transfer/134162/.

65. See Tamar Lewin, Colorado State to Offer Credits for Online Class, N.Y. TIMES (Sept. 6, 2012), http://www.nytimes.com/2012/09/07/education/colorado-stateto-offer-credits-for-online-class.html; see also For Credit Frequently Asked Questions, UDACITY, https://www.udacity.com/for-credit-faq (last visited Oct. 18, 2013) [hereinafter Udacity for Credit FAQ] (web page has since been updated, but PDF version is on file with Villanova Law Review). Regarding testing, see infra notes 83-113 and accompanying text. 
charge for a three-credit course at the university. ${ }^{66}$ A month later, San Jose State University announced that together with Udacity, it would create four mathematics courses and a psychology course. Four of the courses would be offered for college credit-three credits for three of the courses, and four for the course in Introduction to Programming. The courses would cost only $\$ 150$ each, ${ }^{67}$ compared to $\$ 450$ to $\$ 750$ that students would pay for taking the courses in a San Jose State classroom, and Udacity would pocket $49 \%$ of the net revenue, with the university keeping the rest. ${ }^{68}$ The credits earned online would be honored at California State University campuses, and according to Udacity, "[t]he course credits should be transferable to most U.S. universities and colleges." 69 Shortly thereafter, the California State University system announced a collaboration with edX, in which a course called "Circuits and Electronics," taught by three MIT professors, including Anant Agarwal, the edX president, would be offered to students at eleven of the state university's campuses. ${ }^{70}$

It wasn't long before California public officials weighed in to support MOOCs as the answer to problems of high cost and unsatisfied demand in the California system of higher education. ${ }^{71}$ The president pro tempore of the California State Senate introduced a bill ${ }^{72}$ to require educational officials to provide fifty online courses for the most oversubscribed lower division offerings at the University of California, California State, and the state's community colleges. Sebastian Thrun, Udacity's founder, "was involved in discussions that led to the bill."73 The bill would have allowed commercial providers such as Udacity and Coursera to create the courses,

66. See Steve Kolowich, A University's Offer of Credit for a MOOC Gets No Takers, Chron. of Higher Educ. (July 8, 2013), http://chronicle.com/article/A-Universi tys-Offer-of-Credit/140131/.

67. See Udacity for Credit FAQ, supra note 65.

68. See California State U., supra note 14.

69. Udacity for Credit FAQ, supra note 65 (emphasis added). Udacity adds, however, "For confirmation of transferability, please check directly with the registrar of the institution you would like to transfer credit to on their transfer policy." Id.

70. See San Jose State University and edX Announce Course Expansion to 11 of the 23 California State University Campuses, HarvardX (Apr. 10, 2013), http://harvardx .harvard.edu/news/san-jose-state-university-and-edx-announce-course-expansion11-california-state.

71. Actually, the San Jose/Udacity partnership was reportedly initiated by a call from Governor Jerry Brown to Udacity's Sebastian Thrun. See Tamar Lewin \& John Markoff, California to Give Web Courses a Big Trial, N.Y. Times (Jan. 15, 2013), http://www.nytimes.com/2013/01/15/technology/california-to-give-web-coursesa-big-trial.html?_r=0.

72. S.B. 520, 2013-14 Reg. Sess. (Cal. 2013) (as amended through Apr. 25, 2013), available at http://www.leginfo.ca.gov/pub/13-14/bill/sen/sb_0501-0550/ sb_520_bill_20130425_amended_sen_v96.htm.

73. See Lee Gardner \& Jeffrey R. Young, California's Move Toward MOOCs Sends Shock Waves, but Key Questions Remain Unanswered, Chron. of Higher Educ. (Mar. 14, 2013), http://chronicle.com/article/A-Bold-Move-Toward-MOOCs-Sends/137 $903 /$. 
but a panel of faculty members would have to approve them. ${ }^{74}$ As amended shortly thereafter, the bill would, among other things, have required academic officials to:

Develop a list of the 50 most impacted lower division courses [defined as those courses in the state higher education system for which demand most outstrips the supply of seats]... . [F] acilitate partnerships . . . between online course technology providers and faculty of [the state system] . . . with the goal of significantly increasing online course options for students for the fall term of the 2014-15 academic year. . . . [Such courses] shall be deemed to meet the lower division transfer and degree requirements for the University of California, the California State University, and the California Community Colleges. ${ }^{75}$

Each course would have required association by a faculty "sponsor," but the bill did not require that a faculty member teach the course. ${ }^{76}$ The bill was put on the "back burner," however, when California's state universities "promised to expand their own online courses" rather than relying on content provided by profit-making companies. ${ }^{77}$ Florida, however, did pass a MOOC law. It requires state officials to write regulations, within two years, that will allow MOOCs taken before entry into college to be used for college credit. ${ }^{78}$

On the national level, the turn toward MOOCs for credit took a major step forward when the American Council on Education, the "nation's most visible and influential higher education association,"79 with 1,800 members (most of them colleges and universities) endorsed five Coursera MOOCs for credit. This endorsement was touted as a move that "could make the economic significance of MOOCs more tangible." 80 The Council was also in the process of reviewing Udacity courses, and it has received

74. See Dalina Castellanos \& Larry Gordon, California Bill Would Promote Statewide Online College Courses, L.A. Times (Mar. 14, 2013), http://articles.latimes.com/ 2013/mar/14/local/la-me-online-credit-20130314.

75. S.B. 520, 2013-14 Reg. Sess. (Cal. 2013) (as amended through Apr. 25, 2013), available at http://www.leginfo.ca.gov/pub/13-14/bill/sen/sb_0501-0550/ sb_520_bill_20130425_amended_sen_v96.htm.

76. See id.

77. Steve Kolowich, The MOOC 'Revolution' May Not Be as Disruptive as Some Had Imagined, Chron. OF Higher Educ. (Aug. 8, 2013), http://chronicle.com/ article/MOOCs-May-Not-Be-So-Disruptive/140965/.

78. See 2013 Fla. Laws ch. 2013-225 (codified as amended in scattered sections of Title XLVIII of Fla. Stat.); 'Watered Down' MOOC Bill Becomes Law in Florida, Insider Higher ED. (July 1, 2013), http://www.insidehighered.com/quicktakes/ 2013/07/01/watered-down-mooc-bill-becomes-law-florida.

79. See About the American Council on Education, Am. Council on Educ., http:// www.acenet.edu/about-ace/Pages/default.aspx (last visited Nov. 10, 2013).

80. See Steve Kolowich, American Council on Education Recommends 5 MOOCs for Credit, Chron. of Higher Educ. (Feb. 7, 2013), http://chronicle.com/article/ American-Council-on-Education/137155/. 
funds from the Bill \& Melinda Gates Foundation to study how the courses could improve post-secondary education. ${ }^{81}$

In May 2013, Coursera took a further giant step in the direction of making money by providing MOOCs for credit. It announced partnerships with ten large public university systems, including the State University of New York, the University of Tennessee, and the University of Colorado, to create MOOCs that students could take for credit at schools beyond the campuses of the originating system. Coursera would earn $\$ 30$ to $\$ 60$ per student per course taken at a school that had not created the MOOC. 82

\section{Resistance to MOOCs for Credit: The Testing and Grading Problem}

MOOCs for credit have momentum, but there has been resistance to their acceptance by universities. The first problem is a technical one involving testing and grading. Universities insist ferociously on honest work by their students and fair grading of their work by teachers or at least by their graduate student assistants. But how could honesty be assured for a class of 100,000 students taking tests on their computers, and how could so many students' work be graded fairly? The testing problem threatened to derail the MOOC movement before it could thrive.

As noted above, Coursera is attempting to verify the identities of students submitting work by having students submit pictures of themselves and samples of their typing (measuring the "milliseconds" between entries of letters on their keyboards) whenever they submit work. Once any bugs are removed from this system, it might be regarded as a sufficient safeguard for the granting of "verified" certificates from the company, but it is doubtful that universities will have enough faith in this method of proctoring to award college credit on that basis. The MOOC providers are, therefore, working on two other fronts to provide proctored examinations to vast numbers of students.

One method is to hire a proctor to watch an individual student take an online examination with a webcam trained on the student. While hiring a proctor to observe a single student is considerably less cost-effective than hiring a proctor to monitor an entire room full of students, the cost is not prohibitively expensive, particularly if the student (or the university) is being charged hundreds of dollars for the course. In addition, small numbers of students can be assigned identical test times, and one proctor with several screens can monitor up to six students simultaneously. ${ }^{83}$ Both Udacity and Coursera have contracted with "ProctorU," a company that

81. See id.

82. Tamar Lewin, Universities Team with Online Course Provider, N.Y. Times (May 30, 2013), http://www.nytimes.com/2013/05/30/education/universities-teamwith-online-course-provider.html?_r=0.

83. Anne Eisenberg, Keeping an Eye on Online Test-Takers, N.Y. Times (Mar. 3, 2013), http://www.nytimes.com/2013/03/03/technology/new-technologies-aimto-foil-online-course-cheating.html. 
supplies proctors to observe students taking online examinations. The student makes an appointment in advance with ProctorU. As the examination is about to begin, the student allows the proctor to observe him over a webcam, shows government-issued photo identification, answers personal questions from the proctor that the proctor has compiled from "a public information database," and lets the proctor observe, on the proctor's computer screen, whatever the student is typing on his or her own screen. ${ }^{84}$ One measure of the low cost of providing proctors is Udacity's statement that if a student fails to make an appointment for a proctored examination in one of the courses at San Jose State, "the student can connect to a proctor on demand for a late fee of $\$ 8.75$." 85 More realistically, perhaps, Coursera plans to charge each student a $\$ 60$ to $\$ 90$ proctoring fee in the courses it plans to provide for college credit. ${ }^{86}$

While online testing at a time of the student's choice is convenient, and proctors might confirm the identity of a test-taker through photography and observation, ${ }^{87}$ this method cannot prevent students who have taken an examination from sharing the questions with those who take it later. Moreover, "researchers at Ohio University found that students in fully online psychology courses who signed an honor code promising not to cheat broke that pledge at a significantly higher rate than did students in a 'blended' course that took place primarily in a classroom." 88 So the providers are also experimenting with requiring MOOC students to take proctored examinations simultaneously, in person, rather than on line. To provide proctoring for large numbers of students throughout the world, they needed testing centers in many places, just as the College Board has testing centers throughout the world that simultaneously administer the SAT to tens of thousands of college applicants. Private enterprise has already rushed to fill that niche. Both Udacity and edX have

84. See How Online Proctoring Works, ProctorU, http://www.proctoru.com/ howitworks.php (last visited May 15, 2013); see also Udacity for Credit FAQ, supra note 65 (showing Udacity using ProctorU); ProctorU Testing Center, Coursera, http:// www.proctoru.com/portal/coursera/ (last visited Feb. 17, 2014) (showing Coursera using ProctorU).

85. See Udacity for Credit FAQ, supra note 65.

86. See Eisenberg, supra note 83.

87. One expert has opined that computer monitoring, including photography, screen-sharing, and confirming typing styles of test-takers "may end up being as good-or even better-than the live proctoring at bricks-and-mortar universities." See Eisenberg, supra note 83 (citing Douglas H. Fisher, computer science professor at Vanderbilt University).

88. Steve Kolowich, Far from Honorable, Inside Higher Ed (Oct. 25, 2011), http://www.insidehighered.com/news/2011/10/25/online-students-might-feelless-accountable-honor-codes. 
contracted $^{89}$ with Pearson VUE testing centers, which administer proctored tests at 4,400 test centers in more than 160 countries. $^{90}$

Proctoring is one thing, grading quite another. Computers can easily grade unlimited numbers of true-false or short answer questions, as well as mathematics and science examinations in which the answers consist of numerical values. But although MOOCs got their start from computer scientists, non-credit MOOCs have spread to the humanities and social sciences and, as we shall see, to law. In these fields, evaluation has historically required students to write term papers and to take examinations that require essays as answers. How can a MOOC grade tens of thousands taking such courses?

One answer is that the courses might no longer require essays. This is the route taken by the non-credit MOOCs, such as the one given by Professor Scharf, in which the final examination consisted of ten true-false questions. Short answer testing may not satisfy the educational standards of professors or universities, although one Harvard professor who offers a MOOC on Ancient Greek Heroes through edX believes that "multiplechoice questions are almost as good as essays . . . because they spot-check participants' deeper comprehension of the text. ... [The computer] explains the right response when students miss an answer. . [And] lets them see the reasoning behind the correct choice when they're right."91

Recognizing this fact of life, the MOOC providers are trying to develop artificial intelligence software that can grade essay tests instantly. EdX announced that it has already "introduced such a system and will make its automated software available free on the Web to any institution that wants to use it."92 According to the edX announcement, students using the edX software will be required to type their examinations, enabling the computer to analyze them. MOOC teachers will then grade 100 of the essays manually, using either a letter or numerical grading system. The computer will compare any further essays that are submitted to the 100 graded essays and assign grades based on its analysis, ${ }^{93}$ apparently comparing the new essays to those that were graded by the professor. Anant Agarwal, the president of edX, claimed in April 2013, that its

89. See Steve Kolowich, MOOCing on Site, Inside Higher Ed (Sept. 7, 2012), http:/ /www.insidehighered.com/news/2012/09/07/site-based-testing-dealsstrengthen-case-granting-credit-mooc-students; see also edX Testing, PEARson Vue, http://www.pearsonvue.com/edx (last visited Oct. 18, 2013) (web page has since been updated, but PDF version is on file with Villanova Law Review); Udacity, PEARSON VUE, http://www.pearsonvue.com/udacity/ (last visited Oct. 18, 2013).

90. See Test Taker Services, Pearson Vue, http://www.pearsonvue.com/pro grams/ (last visited May 15, 2013).

91. See Heller, supra note 50 (quoting Gregory Nagy).

92. See John Markoff, Essay-Grading Software Offers Professors a Break, N.Y. Times (Apr. 4, 2013), http://www.nytimes.com/2013/04/05/science/new-test-for-computers-grading-essays-at-college-level.html?_r=0 [hereinafter Essay-Grading Software]. The word "introduced" was not defined.

93. See id. 
software was already "good enough" and that "the quality of the grading is similar to the variation you find from instructor to instructor." 94

Although edX's announcement made news around the world, edX's website does not discuss the essay-grading project, describe whether Dr. Agarwal's assessment was based on validation of its software, or, if so, whether the software has been tested with lengthy essays on complex topics in the humanities or social sciences (such as moral philosophy, race relations, or the causes of a war), or whether it was tested only with short essays of the type written in high schools. ${ }^{95}$

There is reason to be skeptical, however, about the ability of presentday computer software to grade subtle or complex essays at the college level, and it is noteworthy that the edX announcement did not suggest that its software was "good enough" for coursework that would be graded for credit. Actually, educators and computer specialists, including those at the Educational Testing Service, ${ }^{96}$ have done a great deal of experimentation with and evaluation of computer-scored essays, but nearly all of this work has involved middle school or high school level work. ${ }^{97}$ Typically, the people who evaluate computer scoring compare how well the grades assigned by computers correlate with the grades independently assigned by human graders, and at least with short middle school and high school essays, they report a high degree of correlation, while warning that "agreement with human ratings is not necessarily the best or only measure of students' writing proficiency."98 One recent experiment did extend computer scoring to the college level, though not to a graded course. It evaluated computer grading of a one-hour freshman English placement test administered at a large Midwestern university to see whether the agreement between the computer's grades and the average of the six human scorers of the same essays was greater or less than the agreement among the six human graders. It concluded that "the computer model out-

94. See id.

95. Four states already use essay-grading technology in secondary schools. See Essay-Grading Software, supra note 92.

96. Educational Testing Service research on computer graded essays is available online at http://www.ets.org/research/topics/as_nlp/written_content/.

97. See, e.g., Mark D. Shermis \& Ben Hamner, Contrasting State-of-the-Art Automated Scoring of Essays: Analysis 10-16 (2012) (unpublished manuscript), available at http://www.scribd.com/doc/91191010/Mark-d-Shermis-2012-contrastingState-Of-The-Art-Automated-Scoring-of-Essays-Analysis; Mark D. Shermis, State-ofthe-Art Automated Essay Scoring: Competition, Results, and Future Directions from a United States Demonstration, Assessing Writing (forthcoming 2014).

98. See Shermis, supra note 97, at 26; see also Brent Bridgeman, Human Ratings and Automated Essay Evaluation, in Handbook of Automated Essay Evaluation: Current Applications and New Directions 221, 229 (Mark D. Shermis \& Jill Burstein eds., 2013) ("The gold standard for developing and evaluating automated essay scoring engines has traditionally been agreement with a human rater when both humans and the machine are evaluating performance on the same prompt [that is, in response to the same question]. Although this standard has the advantage of being relatively easy to compute, it is overly simplistic."). 
perform [ed] the multiple human judges" but it noted that the placement test was a "low-stakes venture," meaning that college grades did not depend on it, and that "it is possible to 'fool' the computer into giving a high grade to a poorly written essay," although "the probability of this being done by a poor writer is small." 99 An additional concern is that computers may grade essays by members of minority groups differently than human graders. The Graduate Record Examination (GRE) uses computers as a check on human scorers; if the computer's grade is very different from that of the human, a second human scorer is called in. The variations between machine and human scorers are greatest for African-American men, who receive slightly higher scores from human graders. ${ }^{100}$

Despite these concerns, machine scoring is capturing the popular imagination because apart from its possible application to MOOCs, improved machine scoring could save hundreds of hours a year for vast numbers of teachers (particularly high school teachers). And if MOOCs for credit become the norm, computer grading of essays could make all the difference, for it is obviously impossible for a professor to grade tens of thousands of students who take an essay-type of examination. The New York Times article reporting on the edX announcement also reported on a contest run by the Hewlett Foundation in 2012, making the connection between the work currently being done on machine-scored high school essays and what may be in store for MOOCs. The foundation provided two $\$ 100,000$ prizes to computer experts who could best improve software to grade essays. More than 150 teams competed, using nine "scoring engines" that had been developed by corporations, non-profit organizations, or universities. ${ }^{101}$ Vik Paruchuri was one of the two winners, and edX promptly hired Paruchuri to design its software. The supervisor of the competition was Mark D. Shermis, a University of Akron professor who has written extensively about essay-grading software. ${ }^{102}$ Along with Ben Hamner of Kaggle, a "big analytics" software company, ${ }^{103}$ Shermis authored a paper about the contest, evaluating the software that was used. Shermis and Hamner concluded that, "the scores of the automated essay scoring engines performed quite well. Most of the mean predictions were within 0.10 of the means of the [human] score."104 This paper itself received almost as much international attention as the edX announcement, ${ }^{105}$ and it was featured in the New York Times article about the edX

99. Mark D. Shermis, Howard R. Mzurmara, Jennifer Olson \& Susanmarie Harrington, Online Grading of Student Essays: PEG Goes on the World Wide Web, 26 Assessment \& Evaluation Higher Educ. 247, 254, 257 (2001).

100. See Bridgeman, supra note 98, at 228.

101. See Shermis \& Hamner, supra note 97.

102. See Markoff, supra note 92.

103. KagGLe, www.kaggle.com (last visited Feb. 18, 2014).

104. See Shermis \& Hamner, supra note 97, at 24.

105. See, e.g. Jim Giles, AI Graders Get Top Marks for Scoring Essay Questions, NEw Scientist (Apr. 25, 2012), http://www.newscientist.com/article/mg21428615.000ai-graders-get-top-marks-for-scoring-essay-questions.html. The contest was based 
announcement that machine grading was "good enough" and "nearing the capability of human grading." 106

Shermis and Hamner were careful to qualify their claims: "Automated essay scoring appears to have developed to the point where it can be reliably applied in both low-stakes assessment (e.g., instructional evaluation of essays) and perhaps as a second scorer for high-stakes testing." 107 But despite their qualification and the fact that most of the research has been limited to middle school and high school level work, both their paper and the whole concept of computer-scored essays have been the subjects of intense criticism, of two types.

First, some educators don't believe that computers can appreciate the subtleties of student writing as humans can, or that they will be able to do so in the foreseeable future. As one secondary school teacher put it:

No software can or will ever be able to discern the stuff that rests between the lines of poetry and prose... . The things left unsaid, or the ambiguous, evocative clues, are as or more important than what is committed to paper. . . . The EdX people ... . [threaten] to dehumanize and digitize a significant part of education, from pre-school to post-graduate. . . Essay-grading software is a horrifying affront to the students whose work is thusly judged... . The least important aspects of their work are the things that software can analyze. Grammar, spelling, punctuation, syntax, the extent to which their writing conforms to 'standard' essay structure . . . Yawn. Who cares? I want to know their ideas, their spirits, their hearts, their doubts and their fears. ${ }^{108}$

In a similar vein, the National Council of Teachers of English issued a position statement stating that:

[High-stakes writing tests] erode the foundations of excellence in writing instruction .... [Because they] ignore the ever-more

on essays submitted by students in grades 7,8 , and 10 . In most cases, the essays were scanned and then transcribed from handwritten submissions, with essays being discarded if they were "illegible . . smudged . . . undecipherable. . . . [O]fftopic or inappropriate." Shermis \& Hamner, supra note 97, at 7. The essays had been graded by human secondary school teachers. The competing computer programmers were given a "training set" for each essay, consisting of a sample of essays, the grades that had been assigned, and the scoring rubrics that the human scorers had used. They provided this data to their computers and used their software to assign grades to the full set of essays. Shermis and Hamner noted that although the computers performed well, "[n] ot unexpectedly, the mean estimates deviated where the scales of the essays were large. So for example, [when] the range of scores ran from 0-60 [the deviation was greater than when] the range only ran from $0-3 . " I d$. at 24.

106. See Markoff, supra note 92.

107. See Shermis \& Hamner, supra note 97, at 27.

108. Steve Nelson, Essay Grading Software Is Insulting, Huffington Post CoLLEGE (Apr. 8, 2013), http://www.huffingtonpost.com/steve-nelson/essay-gradingsoftware-is-insulting_b_3039059.html. 
complex and varied types and uses of writing found in higher education. These concerns . . . are intensified by the use of machine-scoring systems . . . . [M] achines might reduce the costs otherwise associated with the human labor of reading, interpreting, and evaluating the writing of our students. . . . [But] [c]omputers are unable to recognize or judge those elements that we most associate with good writing (logic, clarity, accuracy, ideas relevant to a specific topic, innovative style, effective appeals to audience, different forms of organization, types of persuasion, quality of evidence, humor or irony, and effective uses of repetition, to name just a few)... . [Computer grading also] sends a message to students that writing is not worth their time because reading it is not worth the time of the people teaching and assessing them. ${ }^{109}$

The other critique of computer-graded essays directly challenges the research that has evaluated the current generation of software. For example, Les C. Perelman, formerly MIT's Director of Writing Across the Curriculum, and currently an MIT researcher, published a lengthy critique of the Shermis and Hamner study. ${ }^{110}$ Perelman argues that the experimental design and analysis were flawed, that some of the student essays used for the research were really reading tests, not writing tests, and that different measures were used to assess the differences between human readers and the differences between the computers and the human readers. "The study clearly does not demonstrate that machines can replicate human scores," he concludes. ${ }^{111}$ "Indeed, comparing the performance of human graders matching each other to the machines matching the resolved score still gives some indication that the human raters may be significantly more reliable than machines." 112

Similarly, a group called "Professionals Against Machine Scoring of Student Essays in High-Stakes Assessment" has published an annotated bibliography of critiques of computer-evaluated essay writing. Among other things, this organization cites works that argue that:

$[\mathrm{M}]$ achines cannot score writing tasks long and complex enough to represent levels of writing proficiency or performance acceptable in school, college, or the workplace . . . students who know that they are writing only for a machine may be tempted to turn

109. NCTE Position Statement on Machine Scoring, NAT'L Council of Teachers OF ENGLISH (Apr. 2013), http://www.ncte.org/positions/statements/machine_ scoring.

110. See Les C. Perelman, Critique (Ver. 3.4) of Mark D. Shermis E Ben Hammer, "Contrasting State-of-the-Art Automated Scoring of Essays: Analysis," Mass. Inst. TEсH. (Mar. 13, 2013), http://graphics8.nytimes.com/packages/pdf/science/Cri tique_of_Shermis.pdf.

111. Id. at 10 .

112. Id. 
their writing into a game to fool the machine into producing a higher score, which is easily done ... [and] teachers are coerced into teaching the writing traits that they know the machine will count-surface traits such as essay length, sentence length, trivial grammatical mistakes, mechanics, and topic-related vocabularyand into not teaching the major traits of successful writing-elements such as accuracy, reasoning, organization, critical and creative thinking, and engagement with current knowledge. ${ }^{113}$

Even Elijah Mayfield, a defender of computerized essay grading (and the founder of LightSIDE labs, which competed in the 2012 grading machine competition), was horrified by the edX announcement, as reported in the press. "[T] he popular claims bear only the foggiest resemblance to academic results," he wrote. ${ }^{114}$ "It's unclear to me whether the misunderstanding is due to edX intentionally overselling their product for publicity, or if something got lost in translation while writing the story. . . . It's dangerous and irresponsible for edX to be claiming that 100 hand-graded examples is all that's needed for high-performance machine learning."115 Mayfield suggests that computer-graded learning can supplement other instruction by providing feedback to students during a course, but notwithstanding the "aggressive claims" of edX, is not yet at the stage where it can be used to provide students with a final grade. ${ }^{116}$

\section{E. Resistance to MOOCs for Credit: Doubts About Educational Quality}

The other basis for resistance to MOOCs has come from educators who worry not only about testing but also about the quality of the education. They do not question the caliber of the often highly polished lectures delivered by MOOCs through the medium of videos, but rather whether students can learn as much by watching such lectures-even when MOOCs are enhanced with computer-delivered quizzes and on-line discussion groups-as they can in a traditional classroom.

The backlash apparently began at Amherst College in April 2013, when by a vote of seventy to forty-one, the faculty rejected an offer, sup-

113. Professionals Against Machine Scoring of Student Essays in High-Stakes Assessment, Human ReAdERs, http://humanreaders.org/petition/research_findings.htm (last visited May 22, 2013).

114. Elijah Mayfield, Six Ways the edX Announcement Gets Automated Essay Grading Wrong, E-LiterAte (Apr. 8, 2013), http://mfeldstein.com/si-ways-the-edx-an nouncement-gets-automated-essay-grading-wrong/.

115. See id.

116. See id. EdX's chief engineer on the machine-grading project, Vik Paruchuri, gave an interview that led the interviewer to conclude that the software "is not ready for grading papers, and-at least for now-is not intended to be that sort of tool." Michael Fitzgerald, Automated Essay Grading Software Stirs Debate, InFo. WeEk (Aug. 5, 2013), http://www.informationweek.com/education/instructionalit/automated-essay-grading-software-stirs-d/240159419. 
ported by the college president, to join the edX consortium. ${ }^{117}$ A few days later, the Department of Philosophy at San Jose State, one of the first universities to commit to using MOOCs to lower costs, issued a statement announcing that its teachers would not use materials from the edX course "Justice" offered by Harvard's superstar professor, Michael Sandel. The statement objected to the educational methodology, saying that the prepackaged MOOCs are a "serious compromise of quality of education" for several reasons. First:

Students benefit enormously from interaction with professors engaged in [specialized] research. . . . [I]n classes, independent studies, and informal interaction, they are provided the opportunity to engage a topic deeply .... . [But the] core of edX's JusticeX is a series of videotaped lectures that include excerpts of Harvard students making comments and taking notes. ${ }^{118}$

Second, "familiarity with one's own students [is] simply not available in a one-size-fits-all blended course produced by an outside vendor."119 Third, "the thought of the exact same social justice course being taught in philosophy departments across the country is downright scary-something out of a dystopian novel" because each such department has its own "specializations and character."120 Finally, the advent of MOOCs will mean the creation of two classes of universities: well-funded universities in which "privileged students get their own real professor" and other schools "in which students watch a bunch of video-taped lectures and interact, if in-

117. See Nick Anderson, As Amherst Rejects Online Lecture Model, Educators Ponder What's to Gain from Trend, WASH. Post (May 1, 2013), http://articles.washington post.com/2013-05-01/local/38945447_1_moocs-edx-coursera. Quite likely, the rejection would have been even more resounding if the proposal had come from Coursera or Udacity. At Stanford, which affiliated with Coursera:

$[\mathrm{T}]$ he single most important piece in this controversy [in the Faculty Senate] was the number of faculty in our department who felt blindsided by being encouraged to do this wonderful altruistic thing, making the material available to the world, only to find that there were two [for profit] companies being started on that basis.

Theresa Johnston, Stanford for All, Stanford Magazine, Sept./Oct. 2012, available at http://alumni.stanford.edu/get/page/magazine/article/ ?article_id=55991. Faculty concerns with the profit-making nature of the enterprise might dissipate, however, because the provost has promised that, "Any income that comes in will be shared among the faculty creator and his or her department and school," although he added that: "We have not settled on what the appropriate percentages should be." Id.

118. An Open Letter to Professor Michael Sandel from the Philosophy Department at San Jose State U., Chron. of Higher Educ. (May 2, 2013), http://chronicle.com/ar ticle/The-Document-an-Open-letter/138937/?cid=at\&utm_source=at\&utm_medi um=en.

119. See id.

120. See id. 
deed any interaction is available on their home campuses, with a professor [who has become] a glorified teaching assistant."121

A few days later, after its Arts and Sciences faculty voted against the proposal, Duke University withdrew from a project called "Semester Online" in which, along with a group of other schools, it planned to create "live online courses" that students could take for credit. ${ }^{122}$ Several days after that, American University announced a "moratorium on MOOCs." During the moratorium, individual faculty members were permitted to give online lectures but could not teach full online courses, could not offer online lectures for which students would have to pay or from which students would receive a certificate or credit, and could not engage in grading or assessment of the students. ${ }^{123}$ And the California Faculty Association, representing more than 23,000 teachers, supported the San Jose State teachers by stating that it was "alarmed by the expressed preference" of the University's president for "private rather than public solutions" at California State University. ${ }^{124}$ It also cited research by Shanna Smith Jaggers reporting that "while some students favor online education for various reasons, there is a 'strong underlying pattern: Most students [do] not feel they learn the course material as well when they took it online." 125

121. See id. There appears to be some controversy about whether the administration at San Jose State, which had contracted with edX, had been putting pressure on the philosophy department to use the Sandel course. The provost said that no one had required the department to do so, but several professors said that there had been "administrative pressure" to offer the course to students. After the philosophy department rejected the course, the administration arranged for the English department to offer it, which caused the chair of the philosophy department to express concern that professors not trained in philosophy would have to rely particularly strongly on edX materials. See Tamar Lewin, Professors at San Jose State Criticize Online Courses, N.Y. TIMEs (May 2, 2013), http://www.nytimes.com/ 2013/05/03/education/san-jose-state-philosophy-dept-criticizes-online-courses .html?_r $=0$.

122. Valerie Strauss, Duke University Quits Elite Online Learning Initiative, WASH. Post (May 2, 2013), http://www.washingtonpost.com/blogs/answer-sheet/wp/ 2013/05/02/duke-university-quits-elite-online-learning-initiative/.

123. See Steve Kolowich, As MOOC Debate Simmers at San Jose State, American U. Calls a Halt, Chron. of Higher Educ. (May 9, 2013), http://chronicle.com/article/As-MOOC-Debate-Simmers-at-San/139147/.

124. See CFA Executive Board Responds to Recent Articles in the Chronicle of Higher Education and the New York Times, CAL. FAC. Ass'N (May 8, 2013), http:// www.calfac.org/post/cfa-executive-board-responds-recent-articles-chronicle-high er-education-and-new-york-times.

125. See id. Ms. Jaggers is Assistant Director of the Community College Research Center at Teachers College, Columbia University. Her study of 40,000 students taking online courses concluded that, "online coursework-at least as it is currently and typically implemented-may hinder progression for low-income and underprepared students." See Shanna Smith Jaggers, Online Learning: Does It Help Low-Income and Underprepared Students? (Comty. Coll. Research Ctr., Working Paper No. 26, Jan. 2011), available at http://ccrc.tc.columbia.edu/media/k2/attachments/online-learning-help-students.pdf; see also Di Xu \& Shanna Smith Jaggers, Adaptability to Online Learning: Differences Across Types of Students and Academic Subject Areas, (Comty. Coll. Research Ctr., Working Paper No. 54, Feb. 2013), available at 
Some of the resistance to MOOCs may reflect university teachers' fears that they will be displaced-perhaps actually fired-if their courses are taught online by superstars from elite institutions, such as Professor Sandel. ${ }^{126}$ A variant of this objection is the fear that MOOCs may prompt legislatures to cut their support for state universities. Princeton's Michael Duneier, who was once one of the leading MOOC enthusiasts, stopped teaching his Coursera sociology MOOC when the company asked him to license his course to colleges. He came to believe that state legislatures would use the advent of courses such as his to reduce their support of higher education, and he revealed "serious doubts about whether or not using a course like mine [in a university, rather than for free adult education] would be pedagogically effective."127

Even if professors who are leery about MOOCs are motivated in part by employment concerns, the concerns they raise may be valid. First, the professors usually note that although MOOCs may include discussion groups, online quizzes, and tests, they primarily offer the delivery of content through lectures (in some cases with associated readings) that offer little or no opportunity for interaction with the audience. Because interaction is so limited, students lack the incentive that arises from human contact to do more than the minimum amount of studying necessary to pass a course. ${ }^{128}$ They point out that traditional university educations provide much more than informational lectures in that they offer, among other resources and institutions, small group student discussions, both in the classroom and, importantly, in dorm rooms and coffee shops; clubs,

http:/ / ccrc.tc.columbia.edu/media/k2/attachments/adaptability-to-online-learning.pdf ("While all types of students in the study suffered decrements in performance in online courses, some struggled more than others to adapt: males, younger students, Black students, and students with lower grade point averages."). Students may share the concern that cut-rate online education is not as effective as a class taught by instructors in a college building. In 2013, not a single student took Colorado State University up on its offer to grant three credits for passing Udacity's computer science MOOC, though the reason could have more to do with the non-transferability of the credits to other colleges than with the quality of the course. See Kolowich, supra note 66.

126. The jobs of the teachers at non-elite schools may not be the only jobs threatened. If professors at those schools lose their jobs to MOOCs, there will be even less incentive than there is now for students to enter Ph.D. programs at elite universities with the hope of becoming professors elsewhere. As Ph.D. programs shrink, the faculties of the elite universities will shrink as well. "And every time the faculty shrinks, of course, there are fewer fields and subfields taught. . . . [And] bodies of knowledge are neglected and die." Heller, supra note 50.

127. Marc Parry, A Star MOOC Professor Defects-At Least for Now, Chron. OF Higher Educ. (Sept. 3, 2013), http://chronicle.com/article/A-MOOC-Star-Defects-at-Least/141331/. For further information regarding Professor Duneier's enthusiasm for non-credit MOOCs, see supra notes 31-32 and accompanying text.

128. Even some of the people most enthusiastic about MOOCs acknowledge this problem. Rich Seiter, who has completed 35 MOOCs, "often does minimal work on the essays he submits in courses that require them, and that based on the essays he has seen in peer grading, other students seem to be doing the same." Young, supra note 4. 
sports teams, and other social activities; physical rather than virtual laboratories; professors' office hours in which students and teachers at least occasionally talk one-on-one; placement offices; health clinics; learning disability experts; athletic facilities; and financial aid advisors. Second, they claim that despite their stated goal of democratizing higher education by offering quality courses to everyone, MOOCs will inevitably lead to a two-tier system of education: education on campuses for the well-off, and, for everyone else, "an industrialized version of higher education that . . could replace mid-sized state institutions or less-selective private colleges." 129 In addition, these professors worry that minorities will fare less well as the trend toward online education accelerates. ${ }^{130}$

MOOC enthusiasts dismiss these concerns by observing that the higher education system in the United States already has two tiers (separated largely by the income and educational levels of the students' parents), and that the critics of MOOCs are unaware of the extent to which university education has already become industrialized for those who do not attend elite liberal arts colleges. "At most institutions, students are in mostly large classes, listening to second-rate lecturers, with very little meaningful faculty student interaction," according to Professor Robert Archibald of the College of William and Mary. ${ }^{131}$ This argument was reiterated in a recent New Yorker article on MOOCs:

The vast majority of people who get education beyond high school do so at community colleges and other regional and nonselective schools. ... The teachers there . . . may seem restless and harried. Students may, too. Some attend school part time, juggling their academic work with family or full-time jobs . . . . [This] accounts for about eighty per cent of colleges in the United States. ${ }^{132}$

MOOCs are especially advantageous to students for whom trips to a campus make such "juggling" difficult, and who may need more years to obtain a degree than most colleges allow. In addition, the advocates of MOOCs argue that as a nation, we simply can't afford the type of education we might like to offer to more people, so the world of higher education should be further divided into elite and non-elite categories. According to John Hennessy, the president of Stanford, "If elite universities were to carry the research burden of the whole system, less wellfunded schools could be stripped down and streamlined. Instead of hav-

129. Scott Carlson \& Goldie Blumenstyk, For Whom Is College Being Reinvented?: 'Disruptions' Have the Buzz but May Put Higher Education out of Reach for Those Students Likely to Benefit the Most, Chron. Of Higher Educ. (Dec. 17, 2012), http://chroni cle.com/article/The-False-Promise-of-the/136305/. David Stavens, a Udacity founder, predicted that "the top 50 schools are probably safe." Id.

130. See Smith Jaggers, supra note 125.

131. See Carlson \& Blumenstyk, supra note 129.

132. Heller, supra note 50. 
ing to fuel a fleet of ships, you'd fuel the strongest ones, and let them tug the other boats along." 133

The critics respond that the shabby state of secondary and post-secondary education in the United States is no justification for further stratification, and that instead of embracing the headlong rush to MOOCs for lowcost education for the masses, in a way that will benefit wealthy Silicon Valley entrepreneurs, Americans should demand greater public investment in improving the entire system for all students. ${ }^{134}$

\section{IMPLicATiONS FOR LEgAl EdUCATION}

Legal education is in many ways different from undergraduate education. Nevertheless, three recent developments make the debate that is going on at the college level relevant for law schools as well. First, most law schools are facing an economic crisis. Law school applications declined by $38 \%$ between 2010 and 2013, reaching their lowest level of applications received in thirty years. ${ }^{135}$ First-year law school enrollments also declined, from about 50,000 in 2010 to about 38,000 in $2013,{ }^{136}$ as law schools admitted fewer students either because they did not have enough applicants to fill their classes or because they did not want to lower their standards, fearing either that unqualified students would not be able to keep up with the required work or that accepting students with lower than usual test

133. Id. Apparently, not all university presidents are as enthusiastic as Mr. Hennessy. Teresa A. Sullivan, the president of the University of Virginia, was fired by the University's Board of Visitors in 2012. At least one reason for her dismissal was her disagreement with the trustees that the University needed to move quickly to offer MOOCs. The rector (the Board's chair) had sent a "why we can't afford to wait" email to the vice chair, enclosing a Wall Street Journal column that praised online education for substituting inexpensive technology for expensive labor. Sources reported that Sullivan "had expressed skepticism about the idea that it was a quick fix to solving financial problems, and that she viewed distance education as having the potential to cost a lot of money without delivering financial gains." See Scott Jaschik, The E-Mail Trail at UVA, Inside Higher ED (June 20, 2012), http:// www.insidehighered.com/news/2012/06/20/e-mails-show-uva-board-wanted-bigonline-push. Sullivan's dismissal was later rescinded, and the University started its first MOOC; it is unclear whether those two developments were related. See Scott Jaschik, MOOC Skeptics at the Top, Inside Higher Ed (May 2, 2013), http://www .insidehighered.com/news/2013/05/02/survey-finds-presidents-are-skepticalmoocs.

134. Patricia McGuire, president of Trinity College, warns: "Beware Chicken Little, because Chicken Little has a vested interest in this. There is an awful lot of hype about disruption and the need for reinvention that is being fomented by people who are going to make out like bandits on it." Carlson \& Blumenstky, supra note 129.

135. See Ethan Bronner, Law Schools' Applications Fall as Costs Rise and Jobs Are Cut, N.Y. Times (Jan. 31, 2013), http://www.nytimes.com/2013/01/31/education/law-schools-applications-fall-as-costs-rise-and-jobs-are-cut.html?_r=0\&gwh=DF4 A6E3EDB34D43A0C01DF77199D88CF.

136. Richard Epstein, The Rule of Lawyers, WALL ST. J. (May 6, 2013), http:// online.wsj.com/news/articles/SB10001424127887323494504578342612775060 362. 
scores and grades would precipitate a drop in their U.S. News rank. Three-quarters of accredited law schools experienced declines in first year enrollments. ${ }^{137}$ With less revenue from a smaller class, some law schools laid off staff members and others were expected to do so. ${ }^{138}$ Some have already reduced the size of their faculties by not replacing retiring teachers, ${ }^{139}$ and at least one school notified untenured faculty members that their contracts might not be renewed at the end of the 2013-2014 school year. ${ }^{140}$ But as of 2013, the end was nowhere in sight. Some experts predicted "massive layoffs" during the 2013-2014 school year, ${ }^{141}$ that ten law schools would close within a decade, ${ }^{142}$ or even that "perhaps a dozen" would close "within a year." 143 Furthermore, most experts believe that the recession that started in 2008 precipitated a long-awaited, permanent restructuring of the demand for the services of lawyers, creating a "new normal" in which fewer lawyers are needed, or that it accelerated a restructuring that had begun a few years before the recession started. ${ }^{144}$ If

137. See ABA Section of Legal Education Reports Preliminary Fall 2012 First-Year Enrollment Data, ABA News (Nov. 28, 2010), http://www.americanbar.org/news/ abanews/aba-news-archives/2013/08/aba_section_of_legal.html.

138. See Bronner, supra note 135.

139. Between 2010 and 2013, Hamline University School of Law reduced its faculty size by eighteen percent. See Mark Reilly, Hamline, Other Law Schools Cutting Faculty as Enrollment Dives, Minneapolis/St. Paul Bus. J. (July 17, 2013), http:// www.bizjournals.com/twincities/morning_roundup/2013/07/hamline-other-lawschools-cutting.html.

140. See Victor Fleischer, The Unseen Costs of Cutting Law School Faculty, N.Y. Times DealBook (July 9, 2013), http://dealbook.nytimes.com/2013/07/09/theunseen-costs-of-cutting-law-school-faculty/. Those layoffs were rescinded after several senior faculty members retired or "moved into semi-retirement." David Lat, Law School Rightsizing: This Is How You Do It (Oct. 7, 2013), http://abovethelaw .com/2013/10/law-school-rightsizing-this-is-how-you-do-it/.

141. See Bronner, supra note 135 (quoting William Henderson).

142. See id. (quoting Brian Leiter).

143. See Epstein, supra note 136.

144. See, e.g., Thomas D. Morgan, The Vanishing American Lawyer (2010); Richard Susskind, The End of Lawyers? (2008); Brian Z. Tamanaha, Failing Law Schools 116-18 (2012); see also Claire Zillman, Law Firm Leaders Survey 2010: The New Normal, Am. Law., Dec. 1, 2010, at 67 (showing that most lawyers believe that "the downturn has produced a fundamental shift in the legal marketplace" and reporting that managing partners of law firms "echo" view that recession heralded "long-term change"); Ctr. for the Study of the Legal Profession, Georgetown Univ. Law Ctr., 2013 Report on the State of the Legal Market, Peer Monitor 14 (2013), https://peermonitor.thomsonreuters.com/ThomsonPeer/docs/2013ReportLegalIndustryPeerMonitorGeorgetown.pdf (finding that more than ninety percent of managing partners at large law firms viewed recession as "permanent accelerator of trends that already existed" or "game changer"). The report concluded that, "the economic downturn served as a catalyst that has changed the legal market in fundamental ways." Id. at 20; see also Rick Schmitt, Price and Perils of JD: Is Law School Worth It?, D.C. B. (Mar. 2013), http://www.dcbar.org/for_law yers/resources/publications/washington_lawyer/march_2013/law_school.cfm ("The recession ... . has added to the shock and woe. But structural factors also are playing a role, as corporations and other users of legal services are finding ways to cut their legal costs, which could permanently reduce the number of lawyers 
so, there will be a corresponding permanent downward trend in the demand for legal education. These experts could all be wrong, and the markets for lawyers and for legal education could rebound. But this article assumes that the consensus of experts is more likely than not to be an accurate forecast.

The decline in applications resulted not only from reports about a declining market for legal services but also from the fact that for a long time, law school tuition and the average debt of graduating students had risen considerably faster than the consumer price index, apparently an inevitable result of economic factors known as "Baumol's Cost Disease."145 As early as 1987, Tulane's Dean John R. Kramer had warned about this trend. ${ }^{146}$ The most recent (and widely cited) compilation of data reported that average law school debt (not including undergraduate debt) for students at law schools that were not subsidized by state taxpayers had risen from $\$ 15,676$ in the mid-1980s to $\$ 106,249$ by 2010 , and that average annual tuition at these schools had risen from about $\$ 8,000$ in 1985-1986 to about $\$ 36,000$ by $2009-2010 .^{147}$ The deans of most law schools, and the presidents of their universities, realize that the law schools are on a glide path to extinction unless something arrests the twin trends of rising tuition and declining enrollments.

The second recent development that should focus the attention of law school administrators, faculty and students on the rise of MOOCs is

needed in the future.”); Milton C. Regan, Jr. \& Palmer T. Heenan, Supply Chains and Porous Boundaries: The Disaggregation of Legal Services, 78 Fordham L. Rev. 2137, 2138-42 (2010) (discussing trend toward outsourcing by law firms to lower cost of services).

145. The economist William Baumol explained that when some industries achieved gains in productivity more rapidly than the gains achieved in other industries, prices would rise in the industries with small or no productivity gains. Productivity in the computer industry (among others) has increased very rapidly, allowing companies in that industry to raise wages without raising prices. Industries competing for talented labor had to raise prices to keep up, but in some industries, increases in productivity are virtually impossible. Baumol's famous example is the string quartet; it takes just as much labor to play such a quartet in the twenty-first century as in the eighteenth century. Similarly, it takes just as much labor to teach a class of thirty students in the twenty-first century as in the twentieth century. See James Surowiecki, What Ails Us, The New Yorker (July 7, 2003), http://www.newyorker.com/archive/2003/07/07/030707ta_talk_surowiecki. In higher education, "the only way to reduce costs is either to increase the number of students each professor teaches or to outsource the work to poorly paid adjuncts." $I d$. Only by vastly increasing the student to teacher ratio can productivity in education be increased. But MOOCs present the question of whether the apparent productivity increases represented by online education are genuine or merely the façade of more efficient education, providing more credit for less cost, but perhaps without genuine advances in learning.

146. See generally John R. Kramer, Will Legal Education Remain Affordable, by Whom, and How?, 1987 Duke L.J. 240 (1987); see also Philip G. Schrag, The Federal Income-Contingent Repayment Option for Law Student Loans, 29 HofsTRA L. REv. 733, 740-49 (2001).

147. See Tamanaha, supra note 144, at 109, 129. 
that they are not just the coming attraction for undergraduate institutions: they are already a presence in the field of law. In 2013, Case Western Reserve's Professor Michael Scharf offered a Coursera MOOC on International Criminal Law, the University of London's Dame Hazel Genn taught a Coursera MOOC on English Common Law, Harvard's Professor William Fisher offered an edX MOOC on Copyright Law, and Yale's Professor Akhil Amar is currently providing a Coursera MOOC on Constitutional Law. ${ }^{148}$ Those are all non-credit courses, but the University of Akron School of Law has already offered an online course, for J.D. credit, in Commercial Paper, and Case Western and Cleveland-Marshall law schools are reportedly considering offering, for J.D. credit, "several courses conducted solely through online lectures and tests." 149

The third such development is that entire online graduate degrees are already on the market. Georgia Tech offers a graduate degree through a series of Udacity courses: a master's degree in Computer Science for thousands of students. The students will have to pay only about $\$ 7,000$ for the three-year program. Sixty percent of the revenue will go to the university, and forty percent to Udacity, and students will take tests at any of the four thousand proctored testing centers of Pearson VUE. ${ }^{150}$ So with law school facing horrendous financial pressures, MOOCs by famous professors on important fields of law already in production and use, and reputable universities beginning to offer low-cost degrees for credit over the internet, it can't be long before law school administrators begin to think of MOOCs as the answer, or at least a partial answer, to lowering costs and attracting students and their tuition dollars.

On a smaller scale, but closer to home for legal education, several law schools are already offering LL.M. degrees online, though not yet through large-enrollment MOOCs. ${ }^{151}$ For example, Washington University Law School is providing an online LL.M. degree in United States Law for foreign students. ${ }^{152}$ It claims to provide "an equally rigorous curriculum as

148. These MOOCs are featured on the Coursera and edX websites.

149. Alison Grant, Cleveland's Law Schools Venture into Cyber Classes, Cleveland Plain Dealer (Jan. 19, 2013), http://www.cleveland.com/business/index.ssf/ 2013/01/clevelands_law_schools_venturi.html. The accreditation standards of the ABA's Section of Legal Education currently allow a limited amount of distance learning for course credit. For a further discussion of distance learning, see infra notes $156-63$.

150. Jeffrey R. Young, Georgia Tech to Offer a MOOC-like Online Master's Degree, at Low Cost, Chron. Of Higher Educ. (May 14, 2013), http://chronicle.com/article/ Ga-Tech-to-Offer-a-MOOC-Like/139245/.

151. Continuing Legal Education programs have also for decades provided distance legal education, but like the new LL.M. courses, they have not yet been offered as MOOCs. See, e.g., On Demand Learning, Practicing L. Inst., http://www .pli.edu/Content/On_Demand/_/N-8vZ1g?Npp=25\&Ns=sort_title—0 (last visited Nov. 12, 2013).

152. See Steve Kolowich, Washington U. Law School to Offer Fully Online Degree, Inside Higher Ed (May 8, 2012), http://www.insidehighered.com/news/2012/ 05/08/washington-u-law-school-offer-fully-online-degree. Several other law 
the on-campus program, with courses taught by the same world-renowned faculty" and specifies that its admissions requirements will be the same as those for students who will be in residence. ${ }^{153}$ Unlike true MOOCs, in which students attend "class" at times of their own convenience, the students will connect at specific times, via webcam, for live discussions (which will evidently require middle-of-the night classes for students in certain time zones). The law school is limiting admission for its first class in order to promise students that there will be no more than fifteen students per class, and is charging $\$ 50,040$, hardly the kind of low-cost education that MOOCs envision, although the students will save the cost of transportation, food, and lodging in the United States. Those who complete the course will receive the same diploma as resident LL.M. students. ${ }^{154}$

Two interrelated obstacles prevent law schools from providing J.D. degrees in whole or in large part through MOOCs: the accreditation standards of the Section of Legal Education of the American Bar Association, and the court rules of most states-California being the most notable exception-that require graduation from an accredited law school as a prerequisite for a license to practice law.

The ABA's Section of Legal Education and Admissions to the Bar is the accrediting body for the nation's law schools. Students may attend unaccredited law schools, but forty-six states require graduation from an accredited law school as a condition for a license to practice law. ${ }^{155}$ At present, an accredited law school must have an academic year with at least 130 days of scheduled classes; law schools must require "regular and punctual class attendance" in courses for at least 58,000 minutes of instructional time (which can be squeezed into two calendar years, but with no reduction in total classroom time), and 45,000 of those minutes must be "in regularly scheduled class sessions at the law school."156 "Distance

schools, including Florida Coastal, New York University, Loyola University Chicago, University of Alabama, and Boston University also offer online LL.M. degrees. See, e.g., Graduate Tax Program, Online, Bos. U. Sch. OF L., http:// landing.onlinetaxllm.bu.edu/master-law/overview-409CD-3561U7.html (last visited Nov. 12, 2013). These are distance learning degree-granting programs, but none of them are large-enrollment, low-cost, computer-based MOOCs. See Executive LL.M. in Tax, N.Y.U. L. SCH., http://www.law.nyu.edu/llmjsd/executivellmtax/index.htm (last visited Nov. 12, 2013) (discussing N.Y.U.'s Executive LL.M. in Tax).

153. The Online Master of Laws (LL.M.) in U.S. Law, WASH. U. L. ScH., http:// onlinelaw.wustl.edu/wp-content/uploads/2013/06/LLM_5982-13-eBrochure-web .pdf (last visited Nov. 11, 2013).

154. See id.

155. See About Us, ABA Sec. Legal Educ. \& Admissions to B., http://www.am ericanbar.org/groups/legal_education/about_us.html (last visited Feb. 17, 2014).

156. See 2012-2013 ABA Standards and Rules of Procedure for Approval of Law Schools 22, ABA Sec. Legal Educ. \& Admissions to B., http://www.americanbar .org/content/dam/aba/publications/misc/legal_education/Standards/2012_ 2013_aba_standards_and_rules.authcheckdam.pdf (last visited Feb. 17, 2014) (referring to Standard 34). Through its Standards Review Committee, the Section is currently considering amending the standard to substitute requirements of eighty- 
learning," including MOOCs may be included in the curriculum, but are subject to certain restrictions: ${ }^{157}$

- A student may not receive more than twelve credits for distance learning courses, a credit being equivalent to at least 700 minutes of instruction.

- A student may not take more than four credits of distance learning in any semester.

- No student may take a distance learning course for credit during the first year of law school. However, a traditional course may incorporate "substantial on-line interaction or other common components of 'distance education' courses" for up to one-third of the instructional time without violating the firstyear restriction, the twelve-credit restriction, or the four-credit per semester restriction. ${ }^{158}$ (Apparently, therefore, under existing accreditation policies, students at a Section-accredited school can be provided with half of their legal education-a twelve-credit semester, plus a third of the "class" time in their other courses-through MOOCs).

- There must be "ample interaction with the instructor and other students both inside and outside the formal structure of the course throughout its duration."159 Depending on whether "the instructor" could be a law school teacher at another school, and on whether "ample interaction" could include merely electronic interaction (i.e., through a threaded discussion board), this standard might preclude offering credit for MOOCs, even within the twelve-credit limit, in which the student merely engaged on a virtual basis with a professor at a distance law school offering a course to thousands of students. However, an official interpretation of the standard provides that: "Law schools shall take steps to provide students in distance education courses opportunities to interact with instructors that equal or exceed the opportunities for such

three and sixty-four semester credit hours (or their equivalent in quarter credit hours for schools on the quarter system) for the requirements of 58,000 and 45,000 minutes of instructional time. See Standards Review Comm., Section of Legal Educ. \& Admissions to the Bar, Am. Bar Ass'n, SRC April 2012 Meeting Materials 29 (Apr. 27-28, 2012), available at http://www.americanbar.org/content/dam/ aba/migrated/2011_build/legal_education/committees/standards_review_docu ments/april2012/20120404_april12_src_meeting_materials.authcheckdam.pdf (suggesting change to Standard 304).

157. See 2012-2013 ABA Standards $\mathcal{E}$ Rules of Procedure for Approval of Law Schools, supra note 156, at 25-26 (referring to requirements and standards for distance learning credit described at Standard 306); see also id. at 22-23 (referring to Standard 304 and 700 minutes per credit requirement described in Interpretation 304-4).

158. Id. at 25-26 (referring to Standard 306 and Interpretation 306-3).

159. Id. at 26 (referring to Standard 306(c)(1)). 
interaction with instructors in a traditional classroom setting." 160 The interpretation does not clarify how a school could know whether its program complies with the "equal or exceed" standard.

- The school must provide "ample monitoring of student effort and accomplishment as the course progresses."161 The standard does not explicitly state that the monitoring must be done by law school personnel; conceivably, if the other standards were satisfied, the standard could be interpreted to permit monitoring by a distant teacher, or by a computer.

- The school must "establish a process that is effective for verifying the identity of students taking distance education courses and protects student privacy." 162

- The school's regular process for approving the curriculum must be used to evaluate the content, method of course delivery, and method of evaluating student performance. ${ }^{163}$

The ABA is already under considerable pressure to relax these standards to permit more distance education, in view of the high and rising cost of traditional classroom-based legal education and the prospect that technology can lower those costs. Some scholars have urged such a change, ${ }^{164}$ but the real impetus comes from the fact that law school tuition has been rising with no end in sight, and the rapid advance of internet-based technology offers a possible respite. Barry Currier advocated for allowing more online legal education for credit when he was the dean of Concord Law School of Kaplan University, an unaccredited online law school. ${ }^{165}$ Currier is now the ABA's Managing Director of Accreditation

160. Id. at 25-26 (referring to Standard 306 and Interpretation 306-4).

161. Id. at 26 (quoting Standard 306(c) (2)).

162. Id. (quoting Standard 306(g)).

163. Id. at 25 (describing Standard 306(a)).

164. See Ray Worthy Campbell, Law School Disruption, 26 Geo. J. Legal Ethics 341, 363 (2013) ("Online instruction may not be, in many ways, as good as a current law school education, but there are reasons to think that it could be good enough."); see also Letter from Rebecca Purdom, Working Grp. for Distance Learning in Legal Educ., to Jeffrey E. Lewis, Chair, ABA Standards Review Comm. (July 9, 2012), available at http://www.americanbar.org/content/dam/aba/migrated/ 2011_build/legal_education/committees/standards_review_documents/20120712 _comment_distance_education_working_group_distance_learning_legal_educa tion.authcheckdam.pdf (commenting on proposed Rule 311, replacing Rule 306).

165. See Barry A. Currier, Improve Legal Education Via Technology E Online Learning, A.B.A. J. (Oct. 15, 2009), http://www.abajournal.com/legalrebels/arti cle/barry_currier_improve_legal_education_via_technology_online_learning/

("The ABA should move, as expeditiously as it can, to revise its approach to distance learning."). Concord and St. Francis are two entirely online law schools. See About St. Francis, St. Francis Sch. OF L., http://www.stfrancislaw.com/school-oflaw-online.php (last visited Nov. 12, 2013); About Us, Concord L. ScH., http://www .concordlawschool.edu/ (last visited Nov. 12, 2013). 
and Legal Education, ${ }^{166}$ directing the staff of the Council of the ABA's Section of Legal Education, which reviews standards for legal education as well as whether law schools are complying with the standards.

The distance learning standards are already in the process of being relaxed by the Council, which has published the proposed revisions for notice and comment by interested parties. ${ }^{167}$ The revised Standard 306 would increase the number of credit hours for online education that a student could receive from twelve to fifteen, would repeal the four credit hour per semester sublimit, and the fifteen credit hours would be counted, as the twelve credit hours are at present, within the sixty-four credit hour requirement for "regularly scheduled classes," as well as the eighty-three credit hour requirement for graduation. ${ }^{168}$ The standard that currently requires that students in distance education courses be able to interact with instructors that "equal or exceed" the opportunities for such interactions in other courses, a standard that suggests at least the possibility of quantitative measurement, would be replaced with one that requires only that there is "regular and substantive interaction" between the faculty member and students, and between students. ${ }^{169}$ In addition, as at present, one-third of each of a student's traditional courses could be comprised of distance education. ${ }^{170}$

While the Council considers accreditation changes that would allow MOOCs a larger role in legal education, the state appellate courts that decide bar licensure may be considering proposals that would change legal education even more radically. Professor Brian Tamanaha's widely read book, Failing Law Schools, proposed, rather unrealistically, that the $\mathrm{ABA}$ require law schools to require only two years of legal education. ${ }^{171}$

166. Barry Currier Is New Managing Director of Accreditation and Legal Education at American Bar Association, ABA News (Mar. 28, 2013), http://www.americanbar.org/ news/abanews/aba-news-archives/2013/08/barry_currier_isnew.html.

167. Memorandum from Solomon Oliver, Jr., Council Chairperson, ABA Section of Legal Educ. \& Admissions to the Bar, and Barry A. Currier, Managing Dir. of Accreditation and Legal Educ., ABA, to Interested Persons and Entities (Sept. 6, 2013), available at http://www.americanbar.org/content/dam/aba/administra tive/legal_education_and_admissions_to_the_bar/council_reports_and_resolu tions/20130906_notice_comment_chs_1_3_4_s203b_s603d.authcheckdam.pdf (commenting on Comprehensive Review of ABA Standards for Approval of Law School Matters for Notice and Comment).

168. See id. Under the revised standards, students would have to take eightythree semester credit hours to graduate, of which sixty-four would have to be in regularly scheduled classes, including online classes. See id. (discussing Proposed Standard 311).

169. See id. (referring to Proposed Standards 306(a) and (d)).

170. See id. (referring to Proposed Standard 306(a)).

171. Tamanaha, supra note 144, at 173 (proposing that requirement be changed from 1120 to 747 hours of classroom instruction). Tamanaha does not offer examples of what a two-year curriculum (approximately sixteen courses) might look like, particularly if the current traditional first year courses are retained. In fact, it is quite difficult to construct such a curriculum that would enable students to explore any degree of specialization or to take courses in a variety 
In an impromptu remark at the end of a speech urging lower-cost university education, President Barack Obama endorsed the call for two-year law school education. ${ }^{172}$ Recognizing that the ABA was unlikely to require less than three years (or eighty-three credit hours) of instruction, Tamanaha suggested an end run that "bypasses the ABA." ${ }^{173} \mathrm{He}$ suggested that state supreme courts retain their bar examinations, but eliminate the requirement that applicants for admission to the bar must first graduate from a law school accredited by the ABA Section of Legal Education. He noted that California does not impose that educational requirement, ${ }^{174}$ and that the eighteen law schools in that state that are accredited only by the State Supreme Court and not by the Section charge "around $\$ 10,000$ " in annual tuition, while all of the Section-accredited law schools in the state charge at least $\$ 30,000$. (California also allows a person to take the bar examination without any law school education, even from an unaccredited school, by studying law for four years under the tutelage of a lawyer. But only thirty-nine people tried to do this in the five years before 2011 , and only $26 \%$ of them passed the bar exam). ${ }^{175}$

Graduates of the Massachusetts School of Law, which is not accredited by the Section (and which teaches some courses online) are eligible to take the Massachusetts or Connecticut bar exams and, if successful, are eligible to be licensed in those states. ${ }^{176}$ After being licensed in Massachusetts, they are eligible immediately to take the bar examination in seven other states, and after practicing for several years, they may also be admit-

of subjects to find out whether they were interested enough in those subjects to pursue them for career purposes. Most likely, students would find themselves in large second-year classes, taking a lockstep curriculum that would be comprised mostly of survey courses in basic areas such as evidence, income taxation, corporations, administrative law, professional responsibility, international law, criminal law and procedure, estates, and employment law. What would be missing would not only be writing seminars and clinical education, but also legal philosophy and history, civil rights and civil liberties, legislation, environmental law, family law, immigration law, antitrust law, gender law, securities regulation, and many other subjects, along with advanced follow-ons to basic courses, such as federal courts, complex litigation, natural resources law, commercial transactions, and the like.

172. See Peter Lattman, Obama Says Law School Should Be Two, Not Three, Years, N.Y. Times DealBook (Aug. 24, 2013), http://dealbook.nytimes.com/2013/08/ 23/obama-says-law-school-should-be-two-years-not-three/?_r=0.

173. TAmanaha, supra note 144 , at 176.

174. See Legal Education, ST. B. of CAL., http://admissions.calbar.ca.gov/Education/LegalEducation/LawSchools.aspx (last visited Nov. 12, 2013). California accepts bar applications from eighteen law schools in the state that are accredited by the Committee of Bar Examiners but not by the Section of Legal Education, and from a substantial number of law schools, such as Concord Law School, that are entirely unaccredited. See id.

175. See Rene Ciria-Cruz, The Path Rarely Taken, Cal. Law. (June 2011), http:/ /www.callawyer.com/Clstory.cfm?eid=916106.

176. Accreditation and Bar Eligibility, MAss. ScH. OF L., http://mslaw.edu/ac creditation-bar-eligibility/ (last visited Nov. 12, 2013). 
ted in other states. ${ }^{177}$ The school continues to petition other states to allow its graduates to take their bar examinations. ${ }^{178}$

Samuel Estreicher, a New York University Law professor, has made a licensing proposal that is somewhat more modest than abolition of the requirement for attending a Section-accredited school. He suggests that New York state (and presumably other states) allow students to be admitted to the bar after two years of law school classes, as New York did for college graduates from 1882 until 1911. ${ }^{179}$ Estreicher's proposal would allow law schools to continue to require three years of education for the J.D. degree but not for obtaining a law license. Estreicher assumes that to retain its students for a third year, schools would try to make the third year of study attractive enough that despite the additional tuition, "aspiring lawyers of substance could not afford to pass [it] up," ${ }^{180}$ but he also recognizes that many schools would not be able to keep their students for three years and that law schools would "sustain financial losses that they cannot recoup," a factor deserving little weight when compared with the interests of the students that they train. ${ }^{181}$ The Estreicher plan may have generated some interest beyond academia. In January 2013, New York University held a conference on Estreicher's idea, at which both he and Tamanaha spoke. The conference was attended by New York Court of Appeals Chief Judge Jonathan Lippman and Associate Judge Victoria A. Graffeo, and by "several members of the New York State Board of Law Examiners."182 Lippman told those present that "the concept deserves serious study."183

So there are two different ways in which traditional legal education could fairly rapidly morph into something very different from the form in which it has taken for the last century: if either the Section of Legal Education relaxes the current restrictions on distance education, or state supreme courts begin to eliminate their requirements for attendance at Section-accredited schools, law schools will have to adapt rather rapidly to a new environment. Even the possibility that these external influences could eliminate the requirement of three years of legal education could cause law schools to cast about quickly for ways to preserve the three-year program by providing a cut-rate version, using distance learning, of which

177. See id.

178. See Kolowich, supra note 152.

179. See generally Samuel Estreicher, The Roosevelt-Cardozo Way: The Case for Bar Eligibility After Two Years of Law School, 15 N.Y.U. J. of Legrs. \& Pub. PoL'y 599 (2012).

180. Id. at 607 .

181. Id. at 609 .

182. The Roosevelt-Cardozo Way: Sitting for the Bar Examination After Two Years of Law School, N.Y.U. ScH. OF L., http://www.law.nyu.edu/centers/judicial/programs/SitforBarExamAfterTwoYears/index.htm (last visited Nov. 12, 2013) (announcing Jan. 18, 2013 conference).

183. Karen Sloan, Experts Debate Two-Year Law School Option, N.Y. L.J. (Jan. 22, 2013), http://www.newyorklawjournal.com/PubArticleNY.jsp?id=1202585158075 \&Experts_Debate_TwoYear_Law_School_Option\&slreturn=20130427165104. 
MOOCs are the most efficient (though not necessarily most effective) variant. If some law schools begin to use MOOC education to the full limit allowed by the existing accreditation rules, providing instruction through MOOCs for approximately half of a student's program of study, and reduced its faculty and staff accordingly in order to lower tuition, the move away from the traditional model of education could snowball rapidly. ${ }^{184}$

\section{A. Should Law Schools Go MOOCy?}

There is reason to think that because of rising costs and student debt, reduced revenues as a result of falling enrollments, and advocacy for twoyear law school programs by no less a figure than the President of the United States, Section-accredited law schools will turn to cost-cutting measures. They are already doing so, and they may explore MOOCs quite seriously as one way to offer education that is less expensive than what they now provide. Within a few years, some of them will probably offer course credit for at least some MOOCs, in compliance with existing or relaxed ABA standards for distance learning. MOOC-based J.D. degrees may follow. But whether the advent of either partial or complete online legal education would be a positive development is a different question.

Legal education achieves many different objectives. Two reports suggest that these include:

- Providing students with information about legal doctrine and institutions;

- Giving them tools for organizing massive amounts of information;

184. For a discussion of MOOC education, see infra notes 185-93 and accompanying text. On the other hand, most law schools might reduce faculty size drastically, require faculty members to teach many more courses per year, slash salaries, and relinquish aspirations for faculty to produce scholarship, before moving a significant portion of teaching to a largely unproved distance learning model, in part out of fear that a rapid move in the direction of MOOCs or other distance learning methods could cause rapid declines in their U.S. News rankings. I am grateful to Professor Zachary Schrag for this observation. Tamanaha would apparently approve of an increase in teaching loads and a reduction in scholarly output; he writes that:

We must inquire whether it is appropriate that law students are forced to pay for the production of scholarship at current levels and to the same extent at law schools across the board. Not all law schools and not all law professors must be oriented toward research. . . . [S] ociety would not suffer if the mountain of writing now coming out of law faculties is cut down to a less extravagant size.

See Tamanaha, supra note 144, at 61. Marc Galanter opines that "just how much value there is in the research product of law faculties" is "an interesting empirical question." He wonders whether it would be better to limit scholarship at most law schools and create, instead, "a dozen 'Max Planck'-type institutes where full time research professors surrounded by apprentice researchers could conduct longterm sophisticated projects that would be published in peer-reviewed [electronic] "journals." E-mail from Marc Galanter to author (July 9, 2013) (on file with author). 
- Teaching modes of analysis that are different from those of an undergraduate education; ${ }^{185}$

- Enabling students to see the relationships between legal rules and social and economic policies;

- Inculcating students with a sense of justice and enabling them to understand competing concepts of justice;

- Helping them to understand the interactions between conflicting ethical standards;

- Providing them with skills for researching facts and law;

- Guiding them to be able to understand the legal relevance of facts;

- Teaching them the acceptable forms of legal writing, and improving their ability to write successfully within those forms;

- Enabling them to understand dense, complex statutes such as the Internal Revenue Code or the Uniform Commercial Code;

- Giving them the confidence to speak in public;

- Teaching them to work effectively in small groups (such as study groups or journals);

- Teaching them how to set professional standards for themselves;

- Providing them with different perspectives (such as those of litigator, judge, mediator, arbitrator, and legislator);

- Enabling them to work in an environment in which the facts and the law are uncertain and frequently changing;

- Helping them to choose appropriate career fields, or at least an initial job that is personally and professionally satisfying;

- Teaching particular practical (and particularly interpersonal) skills such as interviewing, counseling, negotiation, and witness examination;

- Helping students to identify and name their values and to consider other values, such as those held by faculty members, other students, judges, opinion leaders, and the clients whom they will represent; and

- Providing them with the ability to continue to learn on their own after leaving law school, a skill often called "learning how to learn."186

185. These are what many people mean when they say that law school teaches students to "think like a lawyer." These analytic skills, which students are exposed to intensively in the first year of law school, include reading at a level of detail that is more like analyzing poetry than like reading essays or undergraduate texts; learning to analogize new fact patterns to those of precedents, and to distinguish them from other precedents; and spotting legal issues in a set of facts.

186. Many of these goals were identified in the 1992 MacCrate Report and the 2007 Carnegie Report. See e.g., ABA Section of Legal Educ. \& Admissions to the Bar, Legal Education and Professional Development-An Educational Continuum: Report of the Task Force on Law Schools and the Profession: Narrowing the Gap 5 (1992); William M. Sullivan et al., Educating Lawyers: Preparation for the Profession of Law (2007). 
In addition, law schools are places where deep and lasting friendships are made through common study and law-related activities; this may not be an objective of legal education, but it is an important by-product. Some of the objectives of legal education may be more easily achieved through computer-based distance learning than others. But which are they? If some but not all of the goals of legal education can be achieved online, can legal education be disaggregated in a way that would incorporate MOOCs so as to lower costs and increase value, or at least not substantially decrease the education that future lawyers will need?

Fortunately, some thought has already been given to these questions. In 2000, long before MOOCs were invented in name or substance, Professor Stephen M. Johnson, a member of the Board of Directors of the Center for Computer Assisted Legal Instruction (CALI), wrote about the possible advantages and disadvantages of distance learning for legal education. ${ }^{187}$ Johnson pointed out that for three decades, skills training (including not only clinical education but also training in research and writing) had increasingly become a central focus of the law school curriculum, in part because students, employers, and judges had complained that law schools did not sufficiently prepare their graduates to practice law. ${ }^{188}$ He argued that skills instruction requires students to engage in reflective self-evaluation and also to receive individual evaluation from a qualified teacher. ${ }^{189}$ He noted that students learn skills best by exercising them, preferably in an actual practice setting and, failing that, in a simulation. ${ }^{190}$ Computerized simulations are an "inadequate substitute" even for live simulations, in part because they are unlikely to engage the student on an emotional level and thereby seem artificial. ${ }^{191}$ He also noted that it is difficult to teach "professionalism and values through virtual classes."192 Most saliently, though, Johnson pointed out that most non-clinical legal

187. See generally Stephen M. Johnson, www.LawSchool.edu: Legal Education in the Digital Age, 2000 Wis. L. Rev. 85 (2000).

188. See id. at 104-05.

189. See id. at 107 .

190. For a discussion of the relative merits of live-client clinics and simulations, see Philip G. Schrag, Teaching Legal Ethics Through Role Playing, 12 Legal ETHics 35 (2009); see also Philip G. Schrag \& Michael Meltsner, Report from a CLEPR Colony, 76 Colum. L. Rev. 581 (1976).

191. See Johnson, supra note 187 , at $107 \&$ n.137.

192. Id. at 109. Johnson's conclusion in this regard may be correct, but his reasoning seems incomplete. Johnson argues that students learn professionalism and values by observing their professors and hearing their personal stories "in the classroom, hallway, or clinical setting" and that students will not identify with a "depersonalized speaker on the Web." Id. While some students may be exposed to and inspired by stories of lawyering by their professors, it seems likely that most students hear little, if anything during their law school years about the personal experiences of their teachers, and surely such teaching is not systematic. Professionalism and values can be taught systematically in a well-constructed professional responsibility class that relies heavily on the problem method and on role plays and simulations. See Schrag, supra note 190; see also Lisa G. Lerman \& Philip G. Schrag, Ethical Problems in the Practice of Law (3d ed. 2012). 
education in the United States is based on some version of the Socratic method and that though the Socratic method has had its critics, it is "an important teaching tool in legal education because it encourages students to think on their feet, articulate their views in a coherent manner, and understand the deeper reasoning behind black-letter rules of law." $193 \mathrm{He}$ noted that because the "central features" of the method are "personal interactions and immediacy," it is "impossible to replicate the Socratic method in a classroom-free world." 194

Some educators are more optimistic about the capabilities of technology that they believe will become available before too long. Eli M. Noam, a professor of finance and economics at Columbia, and its director of the Institute for Tele-Information at the business school, sees a bright future for online law schools, because:

Technology will not stand still. In time, there will be realistic simulations of court proceedings, well-crafted lectures by star professors, provided in quality video, even 3-D; "virtual worlds" that provide interactive legal situations and other forms of practice and apprenticeship; simulator programs to practice thinking on one's feet; and wikis and other community tools for peer-to-peer education. ${ }^{195}$

Professor Stephen Ruth adds enthusiastically that "there are technology approaches in MOOC's that can allow face-to-face contact with a local instructor/mentor and other fellow students in a blended format. . . . [And] there would be less need for tenured or tenure-track teachers, since the best lectures and teachers would reach many more students."196

\section{B. What Might Happen: Three Models of the Future}

Predicting the future is of course very hazardous. I will offer a few guesses about what might happen in law schools during the next decade as MOOCs continue to encroach on undergraduate and graduate education. All three of these scenarios that follow ${ }^{197}$ are ones in which legal education will not be as deep and rich as it is today, except for a few students in elite, highly selective schools. In other words, unless there is a major turnaround in the demand for services by lawyers, ${ }^{198}$ we may look back on the

193. See Johnson, supra note 187 , at 110.

194. $I d$.

195. Eli M. Noam, Electronics and the Future of Law Schools, 17 J. ConTemp. LeGAL Issues 51, 59-60 (2008).

196. Stephen Ruth, Can MOOC's and Existing E-Learning Efficiency Paradigms Help Reduce College Costs?, 8 Int'L J. Tech. Teaching \& Learning 21, 29 (2012), available at http://www.sicet.org/journals/ijttl/issue1201/2_Ruth.pdf.

197. The author invites readers to conjure other, perhaps more optimistic scenarios, taking account of present trends, economic realities, and technological changes.

198. This phrasing reflects my belief that there are, and will continue to be, enormous demands for legal services, but not necessarily for such services from 
second half of the twentieth century as the golden age of legal education, to which there is no return. ${ }^{199}$

\section{Law Schools Might Resist MOOCs to the Death (of Most Law Schools)}

Law schools, the Council of the Section of Legal Education, and state supreme courts might largely ignore what the internet has wrought and continue to conduct business as usual. Tuition and graduates' debt will continue to rise, making law school less and less affordable. ${ }^{200}$ After subsisting for a few years by cutting salaries and services, reducing faculty size by not hiring replacements for retirees, increasing teaching loads for those who remain, relying more on low-paid adjunct teachers, and (except for stand-alone law schools) by accepting temporary subsidies from parent universities eager to keep the law schools in business until the subsidies can again flow the other way, some schools-perhaps a dozen, perhaps more-will find themselves unable to balance their books, and they will fold. This process will continue until a new equilibrium is reached between enrollees and first year spaces available. If the market for legal services continues to contract, still more schools will go out of business. A few might be able to stay afloat by offering degrees in addition to the tradi-

lawyers. Other providers, in addition to licensed legal technicians of the sort contemplated by Washington State, include formbooks, self-help internet programs, and non-lawyer friends who may be authorized to provide services in particular settings, such as immigration court hearings. See 8 C.F.R. § 1292.1(a)(3) (2013). For a further discussion of the type of legal technicians contemplated by Washington State, see infra note 201 and accompanying text.

199. These scenarios are all so depressing that the author, who had a fine education a long time ago at a physical law school, thinks that he could not have written this article early in his career and continued to teach. While he does not yet think of himself as a cranky old man, he suspects that he is more able to write about what he thinks will be a downward spiral for much of legal education because he will not have to teach for many decades in the environment he describes. At the same time, he is saddened by all of the scenarios that he imagines may come to pass. He hopes that his predictions are wrong, and that the market for legal services will rebound so much that law schools continue to be able to provide the kind of in-person rather than online education that he enjoyed. For the view that although "online [legal] education is not as good as the best classroom teaching" but "for some students . . . it may be good enough for the kind of learning they have in mind," see Campbell, supra note 164, at 351.

200. Brian Tamanaha argues that law schools are already unaffordable for most applicants. See Tamanaha, supra note 144, at 135-59. He fails to give due weight to the federal government's Pay as You Earn student loan repayment plan, which significantly eases the loan repayment burden for graduates who have high educational debt relative to their incomes. See generally Philip G. Schrag, Failing Law Schools: Brian Tamanaha's Misguided Missile, 26 Geo. J. Legal Ethics 387 (2013). Although his timing is therefore off, the thrust of his argument is sound. Tuition and debt can't simply continue to rise, indefinitely, more rapidly than the consumer price index. Absent an unexpected economic boom that creates many more lucrative law jobs, even if debt can be repaid at a moderate rate, the sticker price of law school will sooner or later-perhaps quite soon-scare off so many applicants that many of the nation's approximately two-hundred accredited law schools will have to lay off staff, then faculty, and then shutter their doors. 
tional J.D.; for example, by providing one-year or two-year programs leading to a new degree for limited licensed legal professionals who could provide routine low-cost services to average-income Americans who do not need the full range of services or expertise that lawyers offer. Those legal fees would be lower than lawyers would charge in part because unlike paraprofessionals who are supervised by lawyers, the licensed professionals would not require supervision by lawyers and they would not have to repay such large educational debt. Washington State has already created a licensing program with this type of service in mind, but it contemplates educating the licensees through apprenticeships rather than at law schools. ${ }^{201}$

Some readers may applaud this scenario, either because they think that the nation has too many lawyers already or because law schools should cease to exist if they don't have a sufficient number of paying customers. There is, however, a large, national unmet need for legal services for lowand moderate-income individuals. ${ }^{202}$ If only the elite law school with very high, ever-increasing tuition remain in business, lawyers in the future will be available only to serve substantial corporations and wealthy individuals who can pay high fees. It would be better to lower the cost of legal education than to provide lawyers only for the wealthy.

A variant of this model is that rather than folding altogether, law schools might be forced by the economics of their industry to reduce the period of instruction to two years (except at "elite law schools" that might attract enough students to a more expensive three-year program), as recommended by Professor Tamanaha, and echoed by President Obama, ${ }^{203}$ with most professors teaching far larger course loads and abandoning aspirations to research. ${ }^{204}$ Tamanaha does not mention MOOCs. Perhaps he would prefer a reduction in the length of time for legal study to the dilution in the quality of education that could accompany a substantial amount of distance learning, or perhaps he thinks that MOOCs would not reduce the cost of legal education by as much as a third.

201. See Order Adopting New APR 28-Limited Practice Rule for Limited License Legal Technicians (Wash. June 15, 2012), available at http://www.courts.wa .gov/content/publicUpload/Press\%20Releases/25700-A-1005.pdf. The State Bar of California is considering recommending a similar program for that state. See Laura Ernde, State Bar to Look at Limited Licensing Practice Program, Cal. ST. B.J. (Feb. 2013), http://www.calbarjournal.com/February2013/TopHeadlines/TH1 .aspx.

202. See, e.g., ABA, Legal Needs and Civil Justice: A Survey of Americans (1994), available at http://www.abanet.org/legalservices/downloads/sclaid/legal needstudy.pdf; see also Legal Servis. Corp., Documenting the Justice Gap in America: The Current Unmet Civil Legal Needs of Low-Income Americans (2009), available at http://www.lafla.org/pdf/justice_Gap09.pdf.

203. See supra note 172 and accompanying text.

204. See TAmanaha, supra note 144 , at 27,45 . 


\section{A Small Number of Elite Law Schools, or Possibly Just One Such School,} Might Serve Nearly All Law Students, Through MOOCs

Alternatively, MOOCs might largely take over from traditional schools as the primary institution through which new lawyers are educated. Aspiring lawyers might continue to attend twenty or more high-prestige law schools. But imagine, for example, that one of those schools offered enough online courses for credit to qualify students for a law degree, and that for a mere $\$ 10,000$, a student could earn a law degree this way. (This scenario presupposes, of course, either that the Section of Legal Education withdraws its restriction on online education, or that state supreme courts cease to require graduation from a school that has the Section's seal of approval and accept online degrees, at least those offered by this hypothetical prestigious institution). A student could earn a law degree for about $6 \%$ of the current cost of law school-less than $6 \%$ if one takes the cost of room and board into account. Why would a prestigious law school offer such an inexpensive degree? Because about 45,000 first-year students enrolled in U.S. law schools in the fall of 2012,205 and if the school offering the MOOC attracted only 35,000 of them, the tuition would bring in $\$ 350$ million in annual revenue. Additional revenue might be expected from students who don't apply to law schools at present because of high tuition and other expenses, or from those (including foreign students, students with full-time jobs, and certain disabled students) for whom attendance at a physical law school would be very inconvenient. And why would a student sign up for a MOOC rather than attend a physical law school? Besides the savings realized by obtaining the degree online, the student would learn from nationally or internationally famous scholars, as opposed to the teachers at a local or regional law school. In addition, today's students are more accustomed than those in preceding generations to getting their information from screens, much to the chagrin of those employed in another industry that is on the ropes: newspapers.

Of course students would realize that large law firms and corporations might prefer to hire lawyers who had attended a physical law school. That is precisely why twenty or more physical law schools might survive the advent of MOOCs for credit, even if one such school cornered the legal education MOOC market. But in a bifurcated market for legal services, in which most of the highest paid, highest prestige jobs already go to graduates of the law schools near the top of the U.S. News rankings, ${ }^{206}$ a student

205. ABA Section of Legal Education Reports Preliminary Fall 2012 First-Year Enrollment Data, supra note 137.

206. See William D. Henderson \& Rachel M. Zahorsky, The Pedigree Problem: Are Law School Ties Choking the Profession?, A.B.A. J. (July 1, 2012), http://www.abajour nal.com/magazine/article/the_pedigree_problem_are_law_school_ties_choking_ the_profession/; TAMANAHA, supra note 144, at 148-49, 148 fig. 12.1. The figure shows the relationship between law school rank and the percentage of 2009 graduates who reported a full-time private sector salary (a proxy for those who have the 
who could not be admitted to a top school might well conclude that her chances of getting one of the most sought-after legal jobs are mediocre at best, so attending online lectures by well-known professors and obtaining a low-cost degree is better than going $\$ 150,000$ into debt to attend a lowranked law school. Under this scenario, half or three quarters of the nation's law schools could be bankrupted within a year or two after a major university first offers a low-cost online law degree.

The student's education would be far less rigorous than what most law schools offer today, with their back-and-forth dialogue even in large firstyear classes, their seminars, their intensive legal writing instruction, their clinics and externships, and their student activities. And the quantity of legal scholarship would become vanishingly small. But advocates of this model would note that even at present, many students do not participate in dialogue with professors, do not attend office hours, and do not sign up for clinics, moot courts, law journals, or other activities. They attend classes (most of the time), take exams, and collect their degrees. In addition, even with present technology, some out-of-class facets of law school could be replicated online. Online journals could be published, with student editors, just as most journals are already edited by students. Students could be assigned by the professor leading the MOOC to write briefs in pending or "moot" cases, and other students could comment on them. ${ }^{207}$ The MOOC director could also provide some group feedback after reading a random sample of submissions. With present technology, grading would probably have to be based on multiple choice examinations taken either at the proctored test centers around the world or through a verified online system based on video observation, keystroke measurement, or other remote techniques.

\section{Law Schools Might Survive, and Even Continue to Offer Three-Year J.D. Degrees, by Incorporating MOOCs into Less Expensive Forms of Their Own Legal Education}

Writing about the market forces that are overwhelming and threatening liberal arts education, Frank Donoghue states that he has painted "what could be called an unremittingly bleak picture of what the future holds in store for humanities professors, and I offer nothing in the way of uplifting solutions to the problems that I describe." ${ }^{208}$ Even my most

better salaries, based on the assumption that those whose incomes are "poor" do not report their jobs in response to inquiries by their law school placement offices); see also Anayat Durrani, Does Law School Rank Determine Success?, L. Crossing, http:/ / www.lawcrossing.com/article/693/Does-Law-School-Rank-Determine-Suc cess/\# (last visited Nov. 12, 2013).

207. See supra notes 55-59 and accompanying text. In Professor Scharf's Coursera MOOC, students are randomly assigned (for the "extra credit" that will yield a certificate of achievement "with distinction") to write arguments for and against the indictment or conviction of real or hypothetical alleged war criminals.

208. Frank Donoghue, The Last Professors: The Corporate University AND the FAte of the Humanities xi (2008). 
hopeful scenario is almost as bleak as his predictions that professors "will be absorbed into broader categories of professionals and service workers" and that the liberal arts model of higher education "is crumbling as college credentials become both more expensive and more explicitly tied to job preparation. With every passing decade, the liberal arts education will increasingly become a luxury item, affordable only to the privileged."209 But perhaps law schools can hang on to a fraction of the identity that has distinguished them by embracing MOOCs to a point and harnessing their ability to provide vast amounts of information in an inexpensive, convenient way, but refusing to give up some of the most distinctive features of their educational models.

In the debates about MOOCs at the undergraduate level, one of the phrases most often used is "blended courses," referring to courses that rely on MOOCs for information delivery (through video lectures, associated readings chosen by the MOOC professor, and bulletin board discussions), and on live teachers (who are sometimes but not always professors) for work with students individually or in small groups to cement the knowledge provided by the lectures, create supplemental exercises, and evaluate papers and essay examinations. ${ }^{210}$ This model might turn professors into "glorified teaching assistants" as the philosophy department at San Jose State put it, ${ }^{211}$ or it might lead to the elimination of most professorial jobs in favor of hiring recent graduates on short term contracts as teaching assistants or tutors under the supervision of a small number of professors or administrators. But it may preserve some semblance of a program of higher education, including legal education, which relies on live interaction between teachers and students.

This model might have some appeal for law schools that are struggling to survive. By reducing faculty and staff and lowering tuition, they might attract enough students to keep afloat in the face of rising costs and threatened competition from inexpensive education that is entirely online. ${ }^{212}$ These schools could reduce costs both by replacing high-priced professorial labor with low-cost entry-level labor, and by reducing the amount of in-school instruction that students would have to pay for, as

209. Id. at xvii.

210. See, e.g., Jimmy Daly, Blended Learning Is a Comfortable Alternative to MOOCs and Online Learning, EDTecH (Jan. 11, 2013), http://www.edtechmagazine.com/ higher/article/2013/01/blended-learning-comfortable-alternative-moocs-and-online-learning-infographic; Tamar Lewin, Adapting to Blended Courses, and Finding Early Benefits, N.Y. Times (Apr. 29, 2013), http://www.nytimes.com/2013/04/30/ education/adapting-to-blended-courses-and-finding-early-benefits.html?_r=1\&\& gwh=C5EE6DE52AD735DB8CFEA116AFD97EC9. Any Google search for terms such as "blended courses" or "blended MOOCs" will turn up dozens of descriptions of such courses, many of them posted by universities already using them.

211. See supra notes 118-21.

212. Even Barry Currier, the most senior staff member of the ABA's Section of Legal Education, "foresees legal education becoming a mix of face-to-face instruction and online coursework, each tapping its strengths." See Grant, supra note 149. 
students could be assigned to watch MOOC lectures by acclaimed professors on their own time, paying a relatively small amount for each MOOC lecture (or course of lectures) because of the economies of scale provided by the internet. The students would go to a physical school to supplement their online education, and they would receive their law degrees from the institution they actually attended. Like the previous model, this one would probably leave the highest ranked law schools untouched, but it would radically and quickly change legal education at most law schools. And it might possibly enable legal education to remain a three-year endeavor while lowering tuition substantially.

With this model, designed not to eliminate law school tuition but to reduce it by thirty-five to fifty percent, law schools would have to study their curricula and programs to determine what they offer that could be replaced by MOOCs and what aspects of their educational models require in-person training. They would have to ascertain approximately what fraction of the education they offer is simply informational and figure out how to separate out the informational aspect of each course and replace it with an appropriate MOOC. They would also have to delegate the thrust of the educational message to one of the leading lecturer-scholars in each field of study, although probably those who would survive the competitions for those roles would be dynamic instructors who could capture the attention and imagination of large numbers of students. One structural possibility (among others) would be to leave the first semester (or year) of law school largely intact, because in the first semester or year, information delivery is so closely tied to the development of analytic skills that require rapid-fire questions and answers, immediate feedback from a professor to observations or questions from students, and instant pulse-taking by professors to understand whether or not the students are following their trains of thought. It may turn out to be the case, however, that most students do not need additional semesters of Socratic dialogue, even though they may need individualized assistance or drill in understanding the doctrinal and institutional information that MOOCs could provide in subsequent semesters. Such assistance, along with exercises, could be offered in groups of thirty or more and integrated temporally with the MOOCs. In other words, a student might watch a video lecture by a nationally prominent teacher at any convenient time (perhaps at a slower or faster speed, and perhaps more than once, and perhaps in a study group that would stop it for discussion) on Mondays and Wednesdays and meet with an instructor-perhaps a recent graduate or an adjunct professor with a full-time job outside the school-to discuss it on Tuesdays and Thursdays. The instructor would also grade an essay examination at the end of the course.

What else can only physical law schools provide, besides small group discussions of, and exercises based on, the information provided electronically? They can and should offer each student at least one writing seminar, and perhaps more than one, as there is no way that a MOOC instructor can discuss original paper topics with thousands to tens of 
thousands of students, read and comment on drafts, and grade the final papers. Clients, employers, judges, and other consumers of legal services want law graduates who can perform legal research and write easily understood memoranda and other analytical documents. MOOCs are not the answer to this need.

Physical law schools should also continue to provide courses in professional responsibility. That particular course is best taught through a problem method that puts students in the roles of lawyers and requires them to make choices among courses of action that reflect desirable but mutually inconsistent values. ${ }^{213}$ In addition, the type of training that MOOCs most self-evidently cannot offer is clinical education. A MOOC cannot replicate the complexities of interacting with clients, supervisors, allies, adversaries, and adjudicators; dealing with constantly-changing facts, finding and interviewing witnesses, threading ethical needles, or the many other tasks with which practicing lawyers daily engage. Here I must disagree with Professor Tamanaha, who states that if legal education is not cut to two years, law schools should turn the third year into apprenticeship programs in which the schools

$[\mathrm{P}]$ lace students on a wholesale basis in already-existing practice settings (law firms, government legal offices, courthouses, etc.) as many law schools already do through 'externship' programs. This is more cost-efficient than in-house clinics. Law school personnel responsible for these programs will not be scholars but experienced staff lawyers-supervisors who monitor outplaced students. $^{214}$

Tamanaha states that the law school would offer "a supplemental educational component on the side." 215 But he provides no details about how either a placement with harried law firm associates or legal services providers, or a "supplemental educational component" could replace the extensive one-on-one supervision and encouragement of reflection that inhouse clinics currently provide. ${ }^{216}$ Nor does he estimate the cost.

213. See Schrag, supra note 190.

214. See Tamanaha, supra note 144 , at 175 . As an alternative, Tamanaha suggests providing full-time assistance from third-year law students to legal services offices or "[p]rivately financed, privately run versions of low-cost legal services" such as tax services. See id.

215. See id.

216. There exists lengthy scholarly literature on the goals, values, and methods of clinical legal education; the many perspectives on it are too numerous to cite here. See, e.g., J.P. Ogilvy \& Karen Czapanskiy, Clinical Legal Education: An Annotated Bibliography (revised 2005) (unpublished manuscript), http://faculty.cua .edu/ogilvy/biblio05clr.htm. For the authors' own perspectives, see PhiLIP G. Schrag \& Michael Meltsner, Reflections on Clinical Legal Education (1998); see also Center for Applied Legal Studies, GeORgEtown L., http://www.law.georgetown .edu/academics/academic-programs/clinical-programs/our-clinics/CALS/ (last visited Nov. 11, 2013) (follow links to Educational Goals and Teaching Methods.) 
The professor-directed clinical experience is poles apart from the MOOC experience and can only be provided by professional educators. If law schools are able to cut costs by providing a significant portion of their education online, clinics should be one of the last, not one of the first, aspects of the current educational model to be jettisoned.

The typical thriving law school ten years from now, ${ }^{217}$ then, might be one in which the first semester, or possibly the first year, would not be very different from the law school of today. But the next four or five semesters would consist largely of MOOC-assisted learning, in which students elect courses, much as they do today, with lectures delivered via internet, from the most gifted law teachers in the nation, to the students' own laptops. Students would go to physical law schools at least twice a week to have small section discussions with lawyers, related to the lectures and to assigned readings. The lawyers would be paid for their time, but not at the levels that professors are currently paid, would hold other full-time or nearly full-time jobs, and would not be expected to do research. A small professorial faculty at each school would teach the first semester and first year courses, the writing seminars, the professional responsibility course, and the clinics, and every student would have a clinical semester (or a semester that was primarily clinical) during the third year of school, closely supervised by a professor. The school would offer J.D. degrees to those who completed the three years of work, but it might also offer degrees after one year to persons training to be limited licensed legal technicians, who would perform routine tasks for low- and moderate-income individuals and small businesses. And these "typical" law schools would exist side-by-side with a few elite, higher-cost law schools that produce and export the MOOCs but provide their students with three years of education that resembles the law school education offered in the first decade of the twenty-first century, further accelerating the bifurcation of the legal profession that Heinz and Laumann described more than thirty years ago. 218

To those of us who had the benefit of a twentieth century legal education, this is not a pretty picture. But nostalgia for the law school of yester-

217. Certain developments could cause major changes to occur even sooner than ten years. As previously noted, the Section of Legal Education could significantly relax the restrictions on distance learning, or state bars could relax admission requirements. Or law school applications and enrollments could fall much further, threatening many schools with imminent bankruptcy unless floated by their universities. But an additional possibility is worth noting. If Congress significantly altered the statutes affecting loans to law students (for example, by capping the amount that a student could borrow for legal education, or by denying loans to students at schools whose graduates did not obtain legal jobs at sufficiently high rates), the present law school structure would begin to crumble almost immediately.

218. See generally John P. Heinz \& Edward O. Laumann, Chicago Lawyers: The Social Structure of the Bar (1982). 
year will not turn back either the clock on the economic or technological changes that seem to occur with increasing velocity.

\section{Conclusion}

MOOCs did not create the crisis in legal education that is provoking the current rush to downsize law schools and that is threatening the very existence of many of them. The recession that has sparked major declines in law school enrollment predated the advent of MOOCs, which burst upon the scene only in 2012, four years after the recession. But MOOCs may become the coup de grace that ultimately dooms traditional legal education at most of the nation's law schools. There are, as of yet, no online J.D. degrees from accredited law schools. But in recent months and years we have seen many developments, referenced in this article, that point the way to radical changes heralded by new technology. These include:

- The foundation and capitalization of two for-profit and one nonprofit corporation to create MOOCs; ${ }^{219}$

- A rapid proliferation of non-credit MOOCs in courses of the type often offered to undergraduates; ${ }^{220}$

- Charges for various levels of certificates for completing MOOCs; ${ }^{221}$

- The awarding of academic credit for MOOCs for undergraduate courses; ${ }^{222}$

- Endorsement of MOOCs for college credit by the American Council on Education; ${ }^{223}$

- State legislative efforts to require colleges to award academic credit for MOOCs; ${ }^{224}$

- The creation of non-credit MOOCs for law school courses; ${ }^{225}$

- The opening of online law schools, whose graduates can be admitted to the bar in some states; ${ }^{226}$

- ABA Section of Legal Education accreditation rules that allow law schools to accept up to twelve credits for courses taken through distance learning, and to include distance learning in all the other courses for up to a third of the student's educational experience; ${ }^{227}$

- ABA Section consideration of expansion of its current limits; ${ }^{228}$

219. See supra notes $8-22$ and accompanying text.

220. See supra notes 23-30 and accompanying text.

221. See supra notes 55-63 and accompanying text.

222. See supra notes $64-82$ and accompanying text.

223. See supra notes $79-80$ and accompanying text.

224. See supra notes 71-78 and accompanying text.

225. See supra note 148 and accompanying text.

226. See supra note 165 and accompanying text.

227. See supra notes $157-63$ and accompanying text.

228. See supra notes $167-70$ and accompanying text. 
- Some law schools already offering credit to J.D. candidates for online courses; ${ }^{229}$

- Some law schools offering entire online LL.M. degrees through distance learning; and ${ }^{230}$

- Steady growth in the debt accumulated by law graduates, while applications to law schools have plummeted. ${ }^{231}$

The ABA Section has its finger in the dike, temporarily holding back an advancing tide that may replace what we think of as law school education with J.D. degrees that are earned entirely online. And state courts have thus far cooperated by not relaxing the requirement that lawyers graduate from Section-accredited law schools. But as the battles over internet pornography, Wikileaks, and digital copyright piracy have shown, technology has a way of overtaking and swamping regulation or, in some cases, forcing radical changes in a regulatory structure.

The simultaneous proliferation of the new MOOC technology and economic turmoil in most law schools may provide a fine opportunity to educate many more people in legal subjects, a democratization of legal education. But the inevitable cost is a decline in the type of legal education that evolved during the twentieth century, which featured not only the transmission of factual knowledge to students but also the opportunity to hone skills in the classroom and clinic and to explore values so that students could become critical thinkers and citizens. Leading universities, including the one at which I teach, are falling over themselves in a rush to join edX or Coursera and become part of the newest wave in law teaching. Their administrators may see the prospect of substantial revenues within a few years, when the MOOCs created by their faculties become required coursework at less prestigious schools. But in the view of this author, if they value the type of education that their law schools offer, they will give considerable thought to what elements of traditional legal education should be preserved, and how MOOCs can interact with and support, rather than destroy within a few years, a system of legal education that the nation's universities have taken a century to develop.

229. See supra note 149 and accompanying text.

230. See supra note 152 and accompanying text.

231. See supra notes $135-47$ and accompanying text. 